\title{
Pour l'honneur? Duelling in the army of Napoleon
}

\author{
Bert Gevaert \\ Hallebardiers/Sint-Michielsgilde Brugge (Belgium) \\ Bert.gevaert@,sint-lodewijkscollege.be
}

\begin{abstract}
Duelling and Napoleonic history go together like a horse and carriage. Though strictly forbidden and disliked by Napoleon, duelling was a very frequent phenomenon in the Grande Armée. It is even possible to speak about a 'duellomanie', which caused many (deadly) victims. Nevertheless, for various reasons soldiers crossed blades and duels went according to certain unwritten rules. After an official invitation to go to a certain place at a certain time, a duel, fought with specific weapons, took place under the watchful eye of seconds. Sometimes these duellists wanted to kill their opponent, but in many duels the only intention was to cause a (light) wound. Although duels were honourable and a symbol of masculinity and bravery, they also caused many soldiers to die, not for their country, but in a fight without purpose.
\end{abstract}

Keywords - saber; blade; smallsword; spadroon; Napoleonic warfare; Napoleon; duelling; Material culture; Historical European Martial Arts (HEMA); History

"An officer can not, may not accept any insult, not even a form of rudeness.

The duel inspires to have respect and many times it folds characters to moderation. I have seen men who, because of their character, are willing to make a lot of noise, are bashers and even more; but when they were standing in front of a sword, they were cowards. Civilians can react as they see right, but an officer who lacks courage, has to be considered a dead man by his comrades; he is not worthy anymore to wear the epaulettes or the officer's spadroon."

Henri Scheltens, Souvenirs d'un grenadier de la garde 1

\footnotetext{
* This article is a further elaboration of Gevaert, The saber in the army of Napoleon, where a brief chapter was dedicated to duelling. The author wishes to thank Filip Bonte, secretary of the Société Fraternel et Philanthropique des Anciens Frères d'Armes d'Empire, for his suggestions. Thanks to Roberto Gotti and Yves Martin for the illustrations. Special thanks go to Ken Broeders, illustrator, graphic novel artist/writer, and expert on Napoleonic matter.
}

11 Scheltens, Souvenirs d'un grenadier de la garde, p. 133. 


\section{INTRODUCTION}

Is it possible to talk about duelling in the army of Napoleon without mentioning the famous movie 'The Duellists' (Ridley Scott, 1977)? In this movie, based on the short story of Joseph Conrad 'The Due', two soldiers of Napoleon meet on the field of honour in a series of duels. According to Conrad, he based his story on the duels between Fournier Sarlovèze (1773-1827) and an officer named Dupont, which took place in a period between 1794 to 1813. In both the movie and the short story the last duel ends with one of the men wasting the shots of his two pistols and being delivered to the mercy to his opponent. With the loser eternally being in debt to the winner, a long series of duels comes to an end. ${ }^{2}$ It is not sure that this series of duels had actually taken place and the entire story of Conrad was based on a doubtful source. ${ }^{3}$ Still, Conrad and Scott had a huge influence on our popular image of duelling. Both movie and novel contributed to a 'romantic' image of duelling in the army of the emperor.

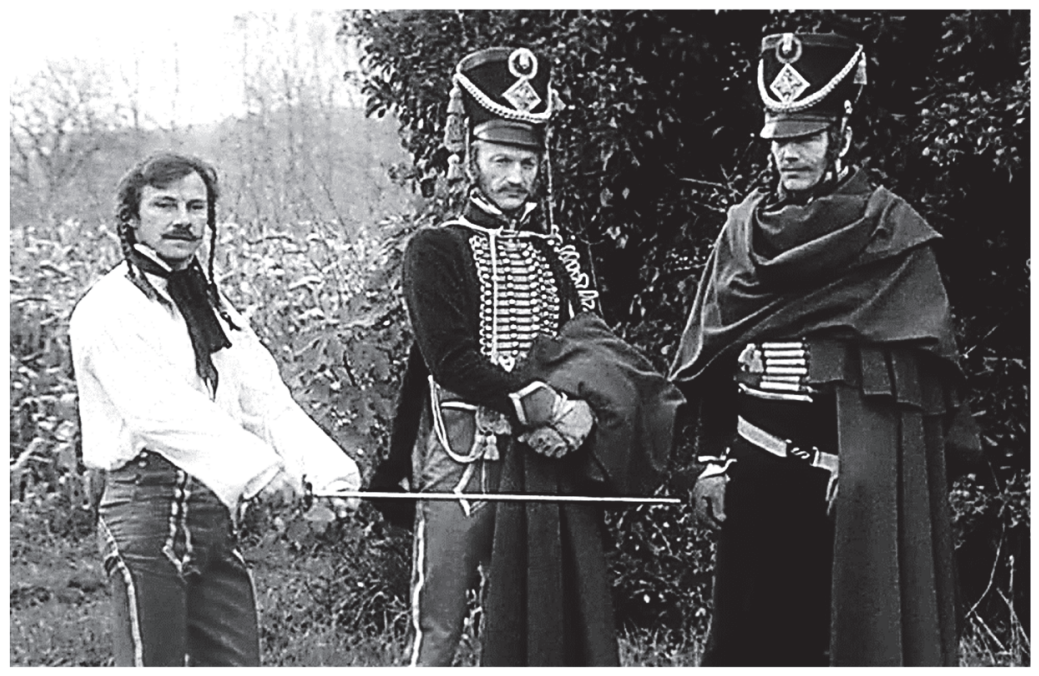

Figure 1: Still from 'The duellists' (Ridley Scott, 1977) Source: https:// streamondemandathome.com/ the-duellists-vod-dvd-blu-rav/

(accessed 24 September 2018)

Everything could cause soldiers to start a duel: from insulting a mistress of a friend, kicking a dog in the presence of its master to a political dispute. There was always a reason

${ }^{2}$ Elting, Swords around a throne: Napoleon’s Grande Armée, pp. 174 and 694.

${ }^{3}$ Sobocinski, 'Celebrating historical accuracy in The duellists', pp. 178-179. Even in recent publications as Norris, Pistols at dawn, p. 37 and Jeanneney, Le duel, p. 51 the story of these famous duellists is considered as historically accurate and mentioned without critical comments. 
to duel. ${ }^{4}$ Some duellists even had special tricks to provoke a duel: in a pub or coffee-bar, they went to a soldier, pointed their finger to their own cheek and told the soldier that they had a black spot on the indicated point. Seeing that the other rubbed his face, the 'duellomaniac' gave the advice to rub a bit higher, adding that there was also a bit of saliva on their clothing. When the other stood up and watched in the mirror, he understood that he had been fooled, an insult that could only be avenged by crossing blades. ${ }^{5}$ It happened that soldiers duelled to the death, without reason, without hatred towards each other, simply to see who was the best fencer amongst them. ${ }^{6}$ A duel could be an affair of honour between two men, but also a fight between two regimental champions who didn't have any personal conflict but only wanted to defend the reputation of their regiment. Sometimes even several people could be involved in a collective duel. ${ }^{7}$

And even though duelling was strictly forbidden, it was an essential part of military culture and one can even speak of a so-called manie des duels or duellomanie in the army of Napoleon. ${ }^{8}$

Duels could happen in a very formal way, or could be fought spontaneously very briefly after the insult or challenge, in this way both combatants could have difficulties to find seconds to assess the fairness of the fight. Nevertheless, a duel was not a normal fight or attempt to murder, because it happened with the agreement of both combatants, who were ready to fight. ${ }^{9}$

In this article the focus will be on duelling with smallswords and sabers by French soldiers in the army of Napoleon, with the exception of the duels of the demi-soldes against foreigners (cfr. infra).$^{10}$ Duels with pistols will also be mentioned briefly, but are not included within the scope of this article. In the Grande Armée the saber was the most preferred weapon and it was - together with the smallsword - a weapon that required more skill than a pistol. In contrast to saber and smallsword, a pistol could be used after just a little bit of instruction. ${ }^{11}$

${ }^{4}$ Groos, 'duel' p. 625 and Pigeard, 'duel' p. 227.

5 Thiébault, Soldier of Napoleon, I, p. 357.

6 Blaze, La vie militaire sous l'Empire, p. 297.

7 Nye, Mascullinity and male codes of honor, $\mathrm{p} 132$.

8 Groos, 'duel', p. 625. Levavasseur explicitly uses the words 'manie des duels' in Souvenirs militaires, p. 20. Blaze also speaks about 'duellomanie' in La vie militaire sous l'Empire, p. 303.

9 Guillet, La mort en face, p. 22.

${ }^{10}$ In this way, the famous series of duels by Jean-Louis Michel (1785-1865) against Italian soldiers, who served under the French flag, will not be mentioned. For more details about this and other of his fights, see Gevaert, The use of the saber in the army of Napoleon, p. 132.

${ }^{11}$ Norris, Pistols at dawn, p. 11. 


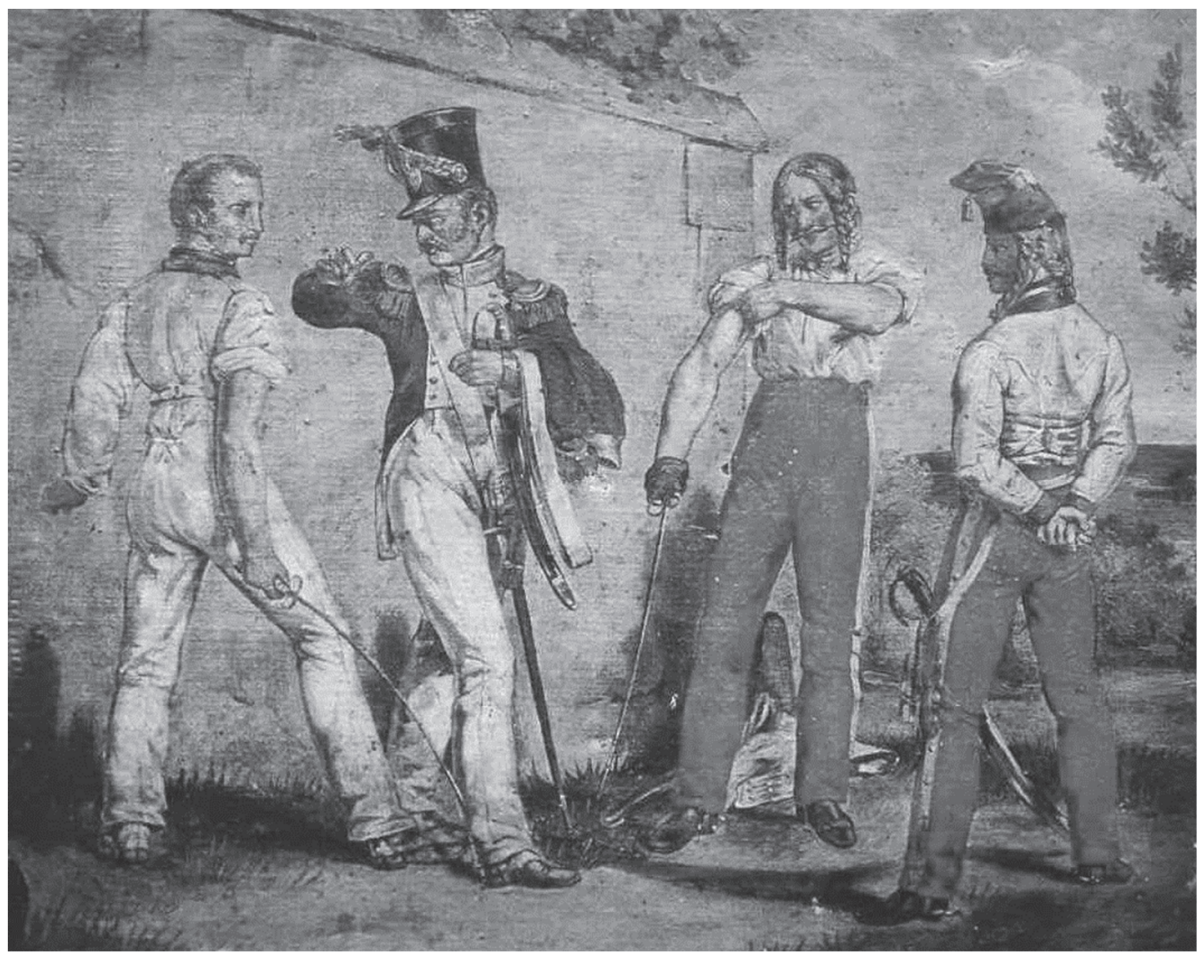

Figure 2: Les suites du jeu de la drogue, by C. de Last after Horace Vernet (1818) La drogue was a game, played with cards, in which the loser had to wear a wooden clothes pin on his nose. Usually this game went along with the consumption of a considerable amount of alcohol, resulting in the drawing of swords or sabers.

(Bibliothèque Nationale de France, Paris)

\section{FRENCH MILITARY LAW ABOUT DUELLING}

Though a French law from 1679 decreed that duellists and their seconds had to be put to death, without a Christian funeral, ${ }^{12}$ no specific law against duelling existed in the empire of Napoleon. In the French Code Pénal of 1810, as in the previous one of 6 October 1791, not one word was mentioned about duelling. ${ }^{13}$ According to Cohen "courts tended to act only when a fatality resulted from a breach of established etiquette."14 This silence about duelling is very surprising, certainly because during the French Revolution there was a tendency to put a ban on duelling, due to the fact that it was seen as a relict of the Ancien

\footnotetext{
${ }^{12}$ Guillet, La mort en face, p. 133.

${ }^{13}$ Briost, Drévillon and Serna, Croiser le fer, pp. 462-463, Jeanneney, Le duel, p. 71 and Nye, Mascullinity and male codes of honor, pp. 133-134.
}

14 Cohen, By the sword, p. 97. 
Régime. Journalist Elysée Loustallot (1761-1790) considered duelling as the triumph of violence and not of law. In his eyes, freedom was only possible when law prevailed over force, so duelling threatened the newly regained liberties of the French Revolution. ${ }^{15}$ Many philosophers and politicians (François Gorgerau, Etienne Barry, Voltaire, Duclos, Rousseau, ...) were against duelling and saw it as a barbarous act, which did not exist in the age of the ancient Greeks, Romans and Gauls. According to them, the only honour for a man was to die for his country and not against a countryman in a duel.16

Despite the moral condemnation, duelling was so common, that it was impossible to eradicate 'the law of duel' and most judges thought that it was much better to leave duelling out of the law and only looked at the consequences of duelling: wounds or worse. ${ }^{17}$ In 1810 the final, unsuccessful, attempt during the reign of Napoleon was made to put a ban on duelling, but lawyer Philippe Antoine Merlin de Douai (1754-1838) strongly defended the right to duel. In line with the classical argumentation to keep duelling out of the law, he claimed that the ordinary laws were enough to punish duellists in case of serious injuries or death. ${ }^{18}$

Officially, duelling was not permitted in the French army and in 1792 an edict stated: "Il est defend de tirer l'épée dans la place"(it is forbidden to draw swords within the walls of a fortress), which was interpreted that it was acceptable to fight outside of the walls of the garrison or encampment. ${ }^{19}$ In a certain way, duelling was encouraged and soldiers who refused to duel could even be punished (e.g. by sending them to a colony) or made redundant..$^{20}$

\section{PUNISHMENT FOR DUELLING}

The general rule for soldiers who were caught duelling or who had duelled was to be put in prison; officers could even receive a degradation..$^{21}$ Extra punishments could be added, e.g. not going into action with the company for a certain period, which could be very dishonourable for officers. ${ }^{22}$

The young Marbot (1782-1854) was insulted by a trumpeter from the artillery and reacted by pushing his fellow soldier in a muddy ditch. Both men agreed to duel, went to a quiet

\footnotetext{
${ }^{15}$ Jeanneney, Le duel, pp. 10-103.

${ }^{16}$ Guillet, La mort en face, pp. 128-129, 140.

17 Ibid., pp. 140-141.

${ }^{18}$ Jeanneney, Le duel, p. 79.

${ }^{19}$ Crowdy, Napoleon's infantry handbook, p. 155 and Guillet, La mort en face, p. 185.

${ }^{20}$ Guillet, La mort en face, p. 186.

${ }^{21}$ Groos, 'duel' p. 626, see also Marbot, Imperial aide-de-camp, p. 38.

22 Marbot, Imperial aide-de-camp, p. 38.
} 
place, removed their dolmans and were ready to fight, sabers in hand. Instead of fighting, the trumpeter chose to run away as fast as he can, followed by insults of Marbot. When Marbot wanted to start a pursuit, two hands of policemen grasped him by the collar and brought him to general Marbot, not knowing that the general was the father of the arrested duellist. General Marbot pretended not to know his son, gave a severe reprimand and ordered to bring the young rascal to the citadel, where he was put in prison. The young Marbot was very upset, not because of the punishment but because of the hard words of his father. Nevertheless, at 10 o'clock in the evening, Marbot was released after a pardon, given by all officers serving under the father of the young hussar. ${ }^{23}$

In his first duel, Charles Parquin (1776-1845) was seriously wounded at his foot and had to stay in hospital for a long time. For his captain this was reason enough not to punish him with fifteen days of prison, a punishment he did give to the opponent of Parquin. ${ }^{24}$

Sometimes officers were very creative in the punishment of duellists. On the road from The Hague to Leiden, chasseur Jacques Chevillet (1786-1837) had a dispute with his colleague Hubert. First they started with punches, but Chevillet wanted to settle the matter for good. They left their regiment and went into the woods and put themselves en garde to fight. At that moment two sergeants arrested them and brought them to the colonel who was very upset about the fight. He ordered both men to walk on foot to Leiden, leading their horses by the bridle, in front of all the soldiers, in order to humiliate them. After several hours of marching and a bottle of gin, Chevillet and Hubert became friends. ${ }^{25}$

The same Chevillet saw another 'alternative' punishment applied to a duellist. The person with whom he wanted to duel was caught by the sergeant-major and his adjutant who gave him a series of blows with the flats of their sabers. Upon seeing this trashing, Chevillet ran away, but later he received a punishment by his captain. During the march, he had to carry a double-barred carbine, which knocked against the bugle of Chevillet and made it impossible to wear his cloak against the bad weather. Later the captain even requested that Chevillet had to carry an extra carbine, only to tease and to humiliate him. Chevillet threw away both carbines and tried to avoid the presence of his captain who wanted to cause him grief. ${ }^{26}$

Not all officers gave (creative) punishments to duellists; instead, they preferred to order or convince them to stop a duel. A good example is marshal Massena (1758-1817) who was very lenient towards duellists and tried to avoid punishing them. ${ }^{27}$

\footnotetext{
23 Marbot, The young hussar, pp. 49-50.

${ }^{24}$ Parquin, Souvenirs, p. 53.

${ }^{25}$ Chevillet, $A$ boy soldier in Napoleon's army, pp. 15-16.

${ }^{26}$ Chevillet, ibid., pp. 60-61.

27 Thiébault, Soldier of Napoleon, I, p. 307-308.
} 
Sometimes military judges were surprisingly soft towards duellists, as in the case of captain Adolphe Lacroix. He pierced his saber several times through the body of his comrade Cognard to be sure that he had really killed him. Nevertheless, the judges didn't punish him, because one of the witnesses claimed that the captain only fought after a provocation from Cognard. Besides that, Lacroix had stayed with the dying Cognard during the last painful moments of his life. ${ }^{28}$

\section{NAPOLEON'S ATTITUDE TOWARDS DUELLING}

\section{IV.1. Napoleon as an idealist}

Napoleon had a very strong dislike of duelling, much like his worst enemy, Arthur Wellesley, the duke of Wellington (1769-1852). Napoleon even tried to introduce a law to prevent officers from duelling, but unfortunately, his proposal didn't have any success. ${ }^{29}$

When Napoleon was challenged to a duel, he simply declined, as was the case when the king of Sweden challenged him to duel with him..$^{30}$ According to Mike Loades, Napoleon would have said: "It's too bad that death often results from duelling, for duels otherwise help to keep up politeness in society." 31 Though this quote seems to say that Napoleon didn't have any problems with duelling, in reality he saw this as a waste of manpower. ${ }^{32}$ According to Elting "he especially disliked the professional duellist, whom he compared to a cannibal." ${ }^{33}$ Cohen also confirms this negative view of Napoleon upon duelling: a good duellist made a bad soldier and besides this, many soldiers in his army had died or were seriously injured because of a matter of honour (cfr. infra). ${ }^{34}$

This explains why Lejeune was very happy that the emperor didn't notice his duelling wounds and the ones of his opponent, one hour after duelling. Even his fellow soldiers didn't notice that Lejeune had disrespected Napoleon's ideas about duelling. ${ }^{35}$

\footnotetext{
${ }^{28}$ Gullet, La mort en face, p. 165.

${ }^{29}$ Norris, Pistols at dawn, pp. 34-35.

${ }^{30}$ Cohen, By the sword, p. 97.

${ }^{31}$ Loades, Swords and swordsmen, p. 459.

32 Jeanneney, Le duel, p. 109 and Nye, Mascullinity and male codes of honor, p. 132.

${ }^{33}$ Elting, Swords around a throne, p. 97.

${ }^{34}$ Cohen, By the sword, p. 97 and Jeanneney, Le duel, p. 109.

35 Lejeune, The Napoleonic wars, I p. 107.
} 


\section{IV.2. Napoleon as a realist}

On the other side, Napoleon was well aware that duelling was part of military life. When he visited the military school of Saint-Cyr around 1811, he expressed his disbelief toward general Ballavène who had told the emperor that his students didn't duel. Napoleon replied that in his time all students duelled. Was it the intention of Napoleon that the day after his visit, many students started to duel in the military academy of Saint-Cyr? ${ }^{36}$

There are several stories of Napoleon not punishing soldiers who had duelled. Once a lieutenant with a duelling wound on his cheek was brought before the emperor, who remembered that he had punished the same soldier some time before on the charge of duelling. With a severe voice the emperor asked him where he had obtained his wound. The soldier didn't want to lie, but also didn't want to tell the truth and replied, pointing his finger on his cheek: 'I got it there, sir.' Napoleon smiled and granted the promotion, but warned the officer to behave better. ${ }^{37} \mathrm{~A}$ similar story about lying to the emperor can be found in the writings of Parquin. When the emperor saw the huge duelling scar on the face of captain Lion, he asked him where the scar came from. Lion replied that it happened in Ulm. On hearing this, the emperor rewarded him because he thought it happened during the Battle of Ulm (16-19 October 1805). Lion didn't lie, because he received the wound in Ulm, not on the battlefield but in a duel... Parquin adds that if the emperor had known this, he would never have rewarded Lion. ${ }^{38}$

\section{ATTITUDE OF OFFICERS TOWARDS DUELLING}

\section{V.1. Between approval and disapproval}

Normally officers had to stand behind Napoleon's negative view on duelling and they had to discourage their men to wound or kill each other. In his memoirs Parquin mentions how commander Joseph Vérigny de la Châsse (1779-1812) prevented a duel between two high-ranked officers, because this would be a very bad example for the army. ${ }^{39}$ Parquin, who became captain of the 2nd chasseurs of the Guard in 1813, followed the example of Vérigny when he discouraged captain Ibrahim Bey and captain Lindzai to duel during the Campagne de France (end of December 1813 till April 1814). He told both men that every French life mattered when France was invaded by foreign forces and with this strong argument he convinced both men to settle the dispute without crossing French blades. ${ }^{40}$

\footnotetext{
36 Groos, 'duel' p. 626. Jeanneney mentions that two students died because of these duels, see Jeanneney, Le Duel, p. 111.

${ }^{37}$ Marbot, Imperial Aide-de-Camp, pp. 38-39.

${ }^{38}$ Parquin, Récits de guerre, p. 43.

39 Parquin, Souvenirs, p. 244.

40 Ibid., p. 353.
} 
During the Battle of Aspern - Essling (21-22 May 1809), marshal Massena (1768-1817) had the same idea in mind when he prevented marshal Lannes (1769-1809) to duel against marshal Bessières (1768-1813). Lannes had made his fellow marshal very furious, claiming that Bessières was parading before the enemy instead of really attacking him. ${ }^{41}$

Nevertheless, it has been said before that many officers closed an eye or were very merciful in their punishments of soldiers who had duelled. Exceptions did exist, as general Jean-Antoine Marbot (1754-1800) who ordered military police to arrest anyone who was engaged in duels and bring them before him. He hated the custom of duelling because he was once a second for a comrade, who had died in a duel caused by a very stupid reason. ${ }^{42}$ Maybe high-ranked officers were more tolerant towards duelling, because they also had a past as a duellist? One of the most famous amongst them was marshal Junot (1771-181) who was wounded in a duel during the Egyptian campaign (1798-1801). ${ }^{43}$

Another marshal, Pierre Augereau (1757-1816) started his career as a fencing master and was a notorious duellist: he even killed an officer following a quarrel. ${ }^{44}$ In his memoirs Marbot (1782-1854) confirms this reputation of marshal Augereau and even adds that the marshal defeated the famous fencing master Saint Martin. ${ }^{45}$

Marshall Michel Ney (1769-1815) probably only duelled once, but his duel enhanced his reputation and made him earn the respect of his comrades. In the year 1791 Ney was still a brigadier and fought against the master-at-arms of the chasseurs, Vintimille, who had previously wounded the master-at-arms of the hussars of Ney's regiment. Because Vintimille kept on insulting the hussars after his victory, the regiment chose Ney to duel against him. Their duel was interrupted and Ney was almost sent to prison. Both men arranged a new meeting and Ney wounded his opponent at the wrist so that the man was disabled forever. Many years later, Ney visited his former adversary, was touched by his poverty and from his own funds, he gave him a royal pension. ${ }^{46}$

Ney was nearly 21 years old when he had this duel, so as most of the other marshals he duelled while he was still at the beginning of his career. Once these promising men rose in the military hierarchy, they had to follow - or tried to follow - the anti-duelling policy of Napoleon.

\footnotetext{
41 Marbot, Imperial aide-de-camp, pp. 121-122.

42 Marbot, The young hussar, p. 48.

${ }^{43}$ Atteridge, Marshal Ney: The bravest of the brave, pp. 8.-9.

44 Haythornthwaite and Courcelle, Napoleon's commanders 1, pp. 28 and 10-11.

${ }^{45}$ Marbot, The young hussar, p. 19.

${ }^{46}$ Guillet, La mort en face, p. 116.
} 




Figure 3: Two French soldiers duelling in an avenue by C.G.H. Geissler (1771-1844) (ASK Brown Collection, Rhode Island)

\section{V.2. A strong voice against duelling: Lejeune}

On campaign in Spain Lejeune was roughly disturbed in his sleep by an interpreter of the army, one of the two brothers Stoffel. Because Lejeune was covered in dirt, the interpreter didn't recognize him as a French officer and behaved very impolitely, roughly saying that he also wanted to sleep in the same barn where Lejeune was trying to rest. Lejeune asked Stoffel to take off his hat as a sign of respect and when this didn't happen, he angrily flinged off the hat and even pushed Stoffel out of his sleeping place. Two days later, the elder Stoffel brother demanded satisfaction for what had happened to his younger brother... 
Before engaging this challenge to a duel, Lejeune - as one of the very few French officers - clearly expressed his opinion about duelling:

What a bother! I said to myself. I, who detest the stupid prejudice which makes it impossible to avoid a duel, am now dragged into one myself. The fear of appearing a coward really is a piece of culpable pusillanimity, and it is a proof rather of want of courage than of the reverse not to dare to express one's aversion to risking one's life in a single combat when there are plenty of other opportunities of proving one's valour in the presence of a thousand dangers. Might not a duel deprive my country of two of its best defenders? Does a duel make a skilful rogue and bully respectable? Or is an honest fellow who falls beneath the sword of a swashbuckler contemptible?47

To this, Lejeune added that people who want to engage in duelling are 'mentally afflicted' and that seconds should try to "effect reconciliation in every case." It would be a great benefit for "society and civilisation" if this "weakness of humanity" and "barbarous custom of rushing to a duel to atone for one offence by committing a yet greater one" would be abolished. ${ }^{48}$

\section{PRACTICAL ‘ORGANISATION’ OF A DUEL}

\section{VI.1. Invitation or challenge}

After a soldier felt offended, he challenged the person who had insulted him to duel. This invitation to fight could be very formal, even with a letter:

Sir,

The behaviour you show towards me is not decent for an officer and it deserves me to demand satisfaction. I wait for you at the other side of the bridge, tomorrow at 5 in the morning and I will correct you by the sword.

Malet

Divisional payer

Acting for the general payer of the Army of Portugal

Mérida, $15^{\text {th }}$ August $1811^{49}$

\footnotetext{
${ }^{47}$ Lejeune, The Napoleonic wars, I p. 105.

48 Ibid., I, p. 105.

49 Parquin, Somvenirs, p. 270.
} 
Usually there was no letter, but only a formal challenge to meet at a certain hour at a certain place with the message to provide the right weapon for the duel.

In certain cases, the formal challenge was nothing more than a request to the other to be en garde and thus be ready to start the fight. It seemed that using the words 'en garde' before the fight was the only difference between a fair duel and a brawl.

\section{VI.2. Place and time}

Usually duels were fought outside the military barracks and duellists tried to avoid crowded places. In this way, forests were the best places, but here fighters had to be extra careful and watch their steps, so they didn't stumble on stumps or branches of trees. Near Paris, the most popular duelling place was the Bois de Boulogne. ${ }^{50}$

When he duelled for the first time, the young Marbot and his opponent went outside of the camp and met near the sea, "on fine solid sand". ${ }^{51}$

Not only in forests it was important to 'prepare' the field where the duel would take place. In the case of the duel between Lejeune and Stoffel, both men chose the place of a former hospital, which was freer of snow than the surrounding area, though they first had to remove the corpses of the previous battle..$^{52}$

Jacques Chevillet chose an isolated ravine to settle his dispute with Cloès, but the terrain was so uneven and covered with so much snow, that Cloès fell in a sinkhole of snow. In his pursuit of Cloès, Chevillet took a wrong step on the stones and also tumbled in the snow, which caused laughter amongst the seconds. ${ }^{53}$

A very strange place to duel was chosen by the opponent of Julien Combe (1790-1867), who wanted their fight to take place in the room of Combe. To make some extra space, they placed the table on the beds, which were placed against the walls of the room. ${ }^{54}$

Not all duellists searched for quiet places to fight. Marbot mentions two young infantry lieutenants who fought a duel in front of their battalion, while cannon-balls of the enemy were flying above their heads. ${ }^{55}$

\footnotetext{
${ }^{50}$ Norris, Pistols at dawn, p. 81.

51 Marbot, The young hussar, p. 48.

52 Lejeune, The Napoleonic wars, I p. 106.

53 Chevillet, $A$ boy soldier in Napoleon's army, pp. 58-59.

54 Combe, Mémoires du colonel Combe, p. 16.

55 Marbot, Imperial Aide-de-Camp, p. 38.
} 


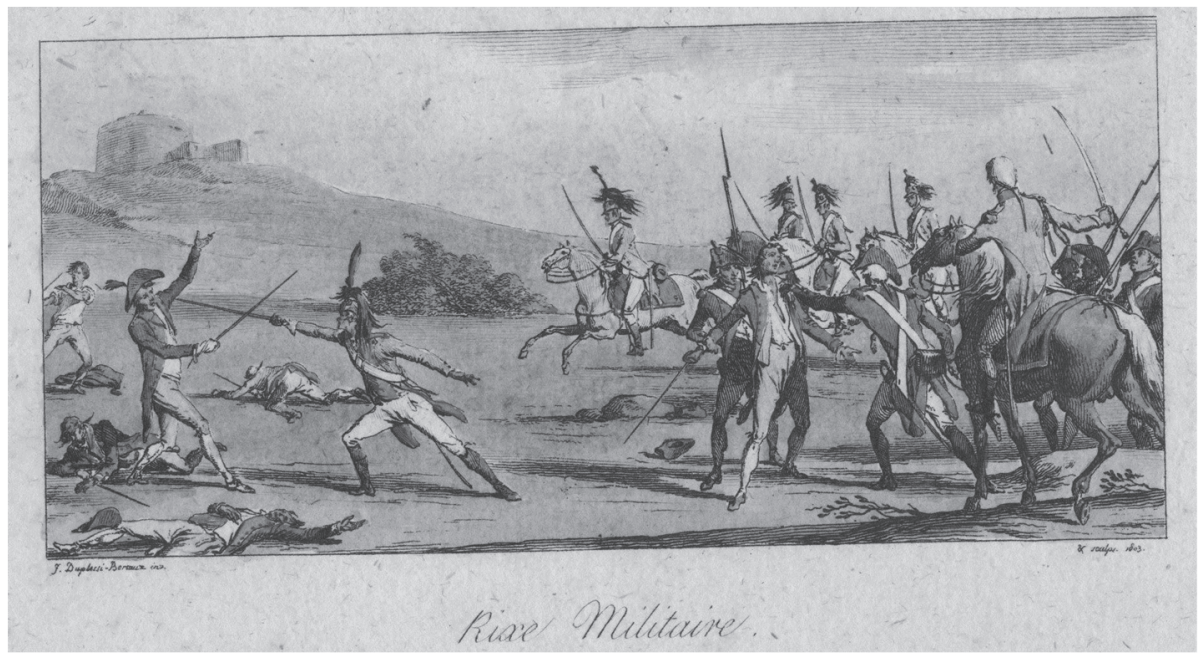

Figure 4: Rixe militaire (military quarrel): soldiers duelling (J. Duplassi, 1803)

(Private collection)

Another way to avoid getting caught was to duel early in the morning, ${ }^{56}$ as can be read in the invitation of Malet to Parquin to fight at 5 am (cfr. supra). As a young man, Paul Thiébault (1769-1846) got pranked by his mother (!) on April fools' day. On the 31st March, she told him that his friend Gassicourt was challenged to duel the next day and that his friend expected him to be there at half past five in the morning as his second. When Thiébault, with his sword under his arm, awoke his friend, the latter immediately understood that his 'second' had been fooled. ${ }^{57}$

\section{VI.3. Seconds}

Normally every duellist brought his own second, a person in charge of witnessing the duel to see if the fight was fair and honourable. Seconds were also important to witness that the fight was a real duel and not an ordinary homicide. For this reason, Elzéar Blaze proposed to solve the problem of duelling by giving seconds a huge fine and several years of prison. In his opinion not one person would ever want to be a second anymore and this will certainly cause the end of duelling. ${ }^{58}$ Seconds agreed on time and place and they could even act as mediators when one of the parties wanted a way of reconciliation. These seconds could also play a role in the choice of weapons. ${ }^{59}$ In duels with pistols, the

\footnotetext{
${ }^{56}$ Guillet, La mort en face, p. 22.

57 Thiébault, Soldier of Napoleon, I, pp. 56-57.

${ }^{58}$ Blaze, La vie sous l'Empire, p. 316.

${ }^{59}$ Cohen, By the sword, p. 97.
} 
seconds prepared the weapons and they were responsible for pacing out the distance and placing their man on the right spot. ${ }^{60}$

In his duel with one of the Stoffel brothers, Lejeune was hoping to use his own brother as his second, but to his regret, his brother was not around. Seeing this, Lejeune asked if the older Stoffel brother could also be his second. ${ }^{61}$ In this way the older Stoffel had to be second to his younger brother and to Lejeune.

Sometimes seconds played a very important role in a duel and even prevented duellists to kill their opponents. Grenadier Henri Scheltens (1790-1880) is witness to the duel of a certain captain Bast. When the latter slips on the stumps of some small bushes and falls down, his opponent grasps the opportunity to deal a fatal blow. Luckily Scheltens parries the incoming saber and saves the life of captain Bast. ${ }^{62}$

Paul Thiébault also takes his role as protector when he is a second of a good friend. Upon seeing that his friend has received a wound on his hand, he immediately strikes down the weapons and places himself between the fighters, thus ending the duel. ${ }^{63}$

Other seconds were too much involved in a duel, as happened to Jacques Chevillet. After he had wounded his opponent Beaumont in the thigh, he stood back en garde and waited for the reaction of Beaumont. Beaumont congratulated Chevillet and said: "That's well done! I deserved it!' Beaumont's second, Degratoulet, was not happy with this result and wanted to take revenge for his friend. Against his will, Chevillet had no other choice than to fight again. At a certain moment during the fight Chevillet has the chance to kill his opponent, but instead he hit him hard with the handguard of his saber, which caused Degratoulet to fall. Another second, Duflot, intervened and brought an end to the duel. The colonel heard from the fight and Chevillet was imprisoned. ${ }^{64}$

\section{VI.4. Weapons}

\section{VI.4.1. Sabers and smallswords}

The most common weapons for duelling in the army were smallswords (or officer's spadroons) and sabers. In the army, the saber was the most preferred weapon because many soldiers carried it, so it was not a problem to find the proper 'tools' to start a duel. The saber was also the most honourable weapon, though it was not as deadly as the

\footnotetext{
60 Norris, Pistols at dawn, p. 81.

${ }^{61}$ Lejeune, The Napoleonic wars, I p. 106.

${ }^{62}$ Scheltens, Souvenirs d'un grenadier de la garde, p. 133.

63 Thiébault, Soldier of Napoleon, I, pp. 307.

64 Chevillet, $A$ boy soldier in Napoleon's army, p. 83.
} 
pistol. ${ }^{65}$ The choice for pistols was usually influenced by an injury to one or both of the duellists, which caused him not to be able to fight with an edged weapon. ${ }^{66}$

Usually sabers were provided with a sword knot (dragonne) to make sure that the combatant would not lose the grip of his weapon during the fight, especially on horseback, or when he was combining his saber with a fire arm. When there was no sword knot, other means to attach the saber to the hand could be provided, as the example of Marbot illustrates.

When the young Marbot is about to fight his first duel, his mentor Pertelay fastened the hilt of Marbot's saber to his hand with a large handkerchief, rolled around the arm of Marbot. ${ }^{67}$

In his duel with Himonet, Parquin broke the saber of his opponent and seeing that his opponent was unable to execute a riposte anymore, he stopped the fight and challenged his opponent to come back after one hour with weapons which would not break. Himonet chose unbuttoned foils, which wounded Himonet so terribly that he had to stay in the hospital for one month. ${ }^{68}$

When Hippolyte d'Espinchal (1777-1864) and his opponent, an army surgeon, disagreed about the choice of weapons because the surgeon claimed only to have experience with the smallsword, they agreed to let fate decide. In the closed hand of a second three straws were held with a different size, indicating saber, sword and the short saber of the infantry (briquet). The straw reminding in the hand of the second indicated the weapon to be used in the duel: fate decided the duel had to be fought with the briquet. The fight didn't last long, because both men didn't have much experience with this infantry weapon, d'Espinchat even called it a 'long kitchen knife'. Both men got wounded in the fight, but the wound of the surgeon was very deep and blooded heavily, so d'Espinchat was the winner. Though the general ws not happy with this duel and even called it a bad example for young officers, the victorious d'Espinchat only received a severe reprimand. ${ }^{69}$

\section{VI.4.2. Other weapons}

When Combe enters the military school at Paris, almost immediately he is bullied and tested by older students, leaving him no other choice than to hit one of these bullies. Immediately he is challenged to a duel in his own room, to be fought out with the bayonet., which was the common duelling weapon in military schools (cfr. infra). At night they meet, holding the bayonet by the socket, a handkerchief wrapped around the right hand. Both men put themselves en garde and Combe parries the first blow. This sound is

\footnotetext{
${ }^{65}$ Gevaert, The use of the saber in the army of Napoleon, p. 146 and Guillet, La mort en face, p. 31-32.

${ }^{66}$ Crowdy, Napoleon's infantry handbook, p. 155.

${ }^{67}$ Marbot, The young hussar, p. 48.

68 Parquin, Souvenirs, pp. 223-224.

${ }^{69}$ D'Espinchat, Souvenirs militaires, pp. 328-329.
} 
heard by the sergeant who hurries to the room and separates both combatants. The sergeant promises not to punish them, but they have to go back to their room... In this way the duel ends without bloodshed, but it showed that Combe was not to be fooled with and made an end to the bullying and testing. ${ }^{70}$

In the case that sabers, swords or other weapons were not available, soldiers were very creative to make their own duelling tools, as Elzéar Blaze (1788-1848) reported:

Duels were frequent at the military school. Before my arrival, it was customary to fight with the bayonet; but one of the pupils having been killed, the use of that weapon was forbidden. This prohibition did not suppress the practice: they would procure pieces of foils, and, in case of need, tie a pair of compasses to the end of a stick; and all to gain the reputation of hair-brained fellows. ${ }^{71}$

French prisoners, who were stationed in prison hulks, also fought their duels. Of course weapons were not available for prisoners, so they also fought with improvised weapons. Norris mentions the story of two French duellists who fought with scissors tied to the end of sticks. With a short spear like this, one of the combatants mortally wounded his opponent by slashing across his abdomen, exposing the entrails of the poor convict. ${ }^{72}$

\section{VI.5. On foot or on horseback}

Usually duels were fought on foot, but there are examples of duels - as in the movie The Duellists - fought out on horseback. After their first duel had to be stopped because both men tumbled in the snow, Cloès and Chevillet still had a matter to settle. When their regiment was on the road, Cloès drew his saber and turned his horse towards Chevillet. The other chasseurs saw how the two men started exchanging saber blows and tried to stop the fight, but Cloès and Chevillet rode away from the regiment to have some space to continue the duel on horseback. The sergeant-major noticed the fight and immediately put an end to the duel.

${ }^{70}$ Combe, Mémoires du colonel Combe, pp. 14-16.

${ }^{71}$ Blaze, Captain Blaze, p. 16.

${ }^{72}$ Norris, Pistols at dawn, p. 152. Norris rightfully remarks that this fight was probably more or less a brawl between prisoners, and had nothing to do with a real formal duel. 




Figure 5: Two soldiers involved in a duel (artist and date unknown)

(Private Collection)

\section{VI.6. Duelling outfit}

It was an unwritten rule that duellists had to fight naked to the waist or with an open shirt. In this way the seconds and duellists could clearly see hidden protective wear. Some duellists even cheated by using mail coloured in flesh colour, with the name of supersticerie. ${ }^{73}$ Not only hidden mail, but also newspapers could protect a duellist against pistol shots $!^{14}$

Though it was the second day of January and the area was full of snow, Lejeune and Stoffel fought bare chested, while their only second - who had to watch for two - held their clothes. ${ }^{75}$

Even when there was no possibility for the duellists to prepare for the duel and the fight was fought immediately after the challenge, it was a custom to fight bare chested, as in

\footnotetext{
${ }^{73}$ Cohen, By the sword, p. 97.

${ }^{74}$ Norris, Pistols at dawn, p. 36.

75 Lejeune, The Napoleonic wars, I p. 106.
} 
the fight of the young recruit Jean-Roch Coignet (1776-1865) against a veteran soldier who wanted to test his courage in a duel. ${ }^{76}$

\section{VI.7. Hierarchy}

According to another unwritten rule of duelling, it was not forbidden for an officer to challenge another officer, much higher in ranking, to duel when the reason to duel had nothing to do with their military life. ${ }^{77}$ In this way it was quite normal that e.g. a lieutenant duelled with a captain when the love for a mistress was at stake. In this kind of duels, they were equals, so the rank didn't matter.

On the other side, many officers didn't make any distinction between their life as a soldier and their life outside the army, so many officers didn't refuse challenges from officers with a lower rank. In brief: hierarchy didn't exist when it came to duelling. ${ }^{78}$ Parquin mentions several duels he personally had to fight against soldiers who were jealous because Parquin was higher in rank: as a corporal (brigadier) against a private ${ }^{79}$ and as a staff-captain (adjudant major) against a lieutenant. ${ }^{80}$

\section{VI.8. Implicit rules, courtesy during and after the fight}

In a duel it was permitted to use both cuts and thrusts, the latter being more deadly. Usually coups de manchette (a cut to the arm) were not allowed and when it happened that a duellist was wounded at the hand or arm, the duel continued as in the case described by Blaze. A young student of de Ecole Polytechnique had insulted the men working on the fortifications near the Island of Lobau at the eve of the Battle of Wagram (5-6 July 1809). Their captain could not accept this insult and defended the honour of his men by a duel. When the student wounded the little finger of the captain, he wanted to stop the fight, but this was refused by the captain. The fight continued and again the captain was wounded, but now at his leg and he had to stop the fight. ${ }^{81}$

Though never explicitly mentioned or described in detail in the army of Napoleon, duels had to follow certain rules of fairness. ${ }^{82}$ If these rules were not respected and both combatants were members of different regiments, a duel could provoke mass fights

${ }^{76}$ Coignet, Cahiers, p. 88.

77 Groos, ‘duel' p. 625.

${ }^{78}$ Guillet, La mort en face, p. 189-190.

${ }^{79}$ Parquin, Souvenirs, p. 48.

${ }^{80}$ Parquin, ibid. p. 223. See also p. 53 (fight between quartermaster and sergeant).

${ }^{81}$ Blaze, La vie sous l'Empire, pp. 309-

${ }^{82}$ The first real French book with rules for duelling since the French Revolution, l'Essai sur le duel, was written by count Chatauvillard in 1836, see Guillet, La mort en face, p. 17 and Jeanneney, Le duel, p. 72 . 
between the comrades of the duellists. Chasseur Victor Dupuy (1777-1851) was almost involved in a fight between 50 grenadiers and 50 chasseurs, who believed that their brother-in-arms, Pelletier, was heavily wounded in an unfair duel. The two groups were about to start a huge fight, when the cantinière came in between and explained that the duel had happened in the right way. The grenadiers and chasseurs shook hands, left the place where they previously wanted to cross blades, after having emptied the cask of the cantinière. A senseless waste of blood had been avoided by this courageous woman!83

Besides these unwritten rules of fairness, a sort of duelling etiquette existed. A fine example of this etiquette can be found in the memoires of captain Parquin who was involved in a duel with smallswords against a certain Malet, after receiving a very formal invitation to duel. His first thrust was deflected by the buckle of the suspenders of Malet and made him bleed slightly. For Parquin's opponent, this was not a real wound, so he wanted to continue the fight. After several exchanges and driving back his adversary, Parquin managed to give him a thrust in the right side, which caused Malet to fall down. Immediately Parquin ran to Malet to help him and even asked his own seconds to help his brave adversary. Together they brought Malet to the army surgeon who told them that the wounded Malet was going to survive his wound without any problem. ${ }^{84}$

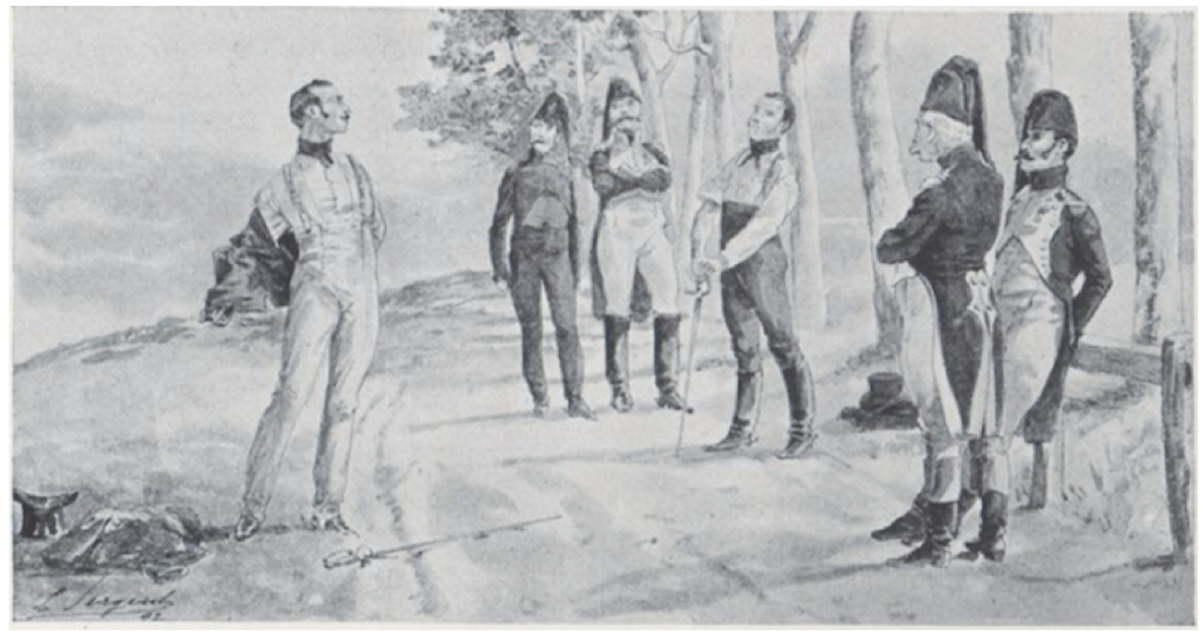

Figure 6: Parquin and Malet are about to duel.

(Parquin, Récits de guerre ([1842], 1892), p. 107)

Involved in a duel when staying at the military academy in Metz, Octave Levavasseur (1781-1866) wounded his opponent Souhalac at the shoulder. The blade of Levavasseur broke and Souhalac couldn't move his arm anymore. Seeing this, Levavasseur pulled out the remaining part of the blade, but no blood was coming out of the wound. For

\footnotetext{
${ }^{83}$ Dupuy, Souvenirs militaires, p. 6.

${ }^{84}$ Parquin, Souvenirs, pp. 271-272.
} 
Levavasseur this was not a normal bodily reaction and in his opinion there was nothing better to do than to suck out the blood. Afterwards the doctors declared that Levavasseur had saved the life of Souhalac by doing this. ${ }^{85}$

One of the main reasons to duel was 'to receive satisfaction'. Once satisfaction received, it was a general rule that fighters accepted the result of the duel and that both fighters would not feel any grudge against each other anymore, even when they were disabled or worse because of the fight.

Parquin describes how a quarter master was wounded in the face, stopped the duel exclaiming:

I will postpone the fight till tomorrow and I need a mask to protect me: this sir over there is a very clumsy person who will pour out an eye of me!

All soldiers who were watching this duel started laughing and both combatants embraced each other. ${ }^{86}$

When Parquin himself left the hospital after his fight with a certain Hayer, he went to his former opponent, shook hands and they became good friends. ${ }^{87}$ The night before the Battle of Dresden (26-27 August 1813), the same Parquin met a soldier with whom he had crossed blades seven years before. First he didn't recognize Auguste, his former opponent but then they thought with joy about their duel from 1806. The day after, when Parquin heared that Auguste had died in the Battle of Dresden, he was very sad. ${ }^{88}$

Elzéar Blaze gives several examples of soldiers who had duelled as friends and even after being heavily wounded, or maybe because of both being wounded, became even better friends. Once two officers were involved in a duel and wanted to arrange their matter in the Bois de Boulogne. The night before the fight, they dined together, had a nice talk and in the morning they shared a carriage to go to the duelling place. Here they had their duel, resulting in one of them being seriously wounded. ${ }^{89}$

An extreme example of courtesy can be found in the writings of general Thiébault who mentions his friend Deslon, fencing champion, doctor, but not a soldier. Deslon had insulted a young officer, because the man bored him during their journey. The officer slapped Deslon in the face and both men began to duel, resulting in a mortal wound brought upon the officer. Before his death, the officer requested that no charges would

\footnotetext{
${ }^{85}$ Levavasseur, Souvenirs militaires.

86 Parquin, Souvenirs, pp. 54-55.

${ }^{87}$ Ibid. p. 53.

${ }^{88}$ Ibid., p. 317-318.

${ }^{89}$ Blaze, La vie militaire sous l'Empire, pp. 301-303.
} 
be put against Deslon. And Deslon? He never forgave himself having killed the young officer... ${ }^{90}$

\section{TYPES OF DUELS}

\section{VII.1. Rite de passage}

Most soldiers of Napoleon had their first - and sometimes only - duel when they were new in the army. When they arrived in their barracks to start their military training, they were tested by older soldiers and in this way the duel can be seen as a sort of 'rite de passage'. A duel, and the first blood, was also a way of preparing the young soldier for the 'real work' on the battlefield, where edged weapons could still play an important role. ${ }^{11}$

Only four days after arriving in the barracks, carabinier Joseph Abbeel (1786-1866) was challenged to duel. Though his challenger, a certain Bonnaire, had been in the same barracks maximum one week longer, he called Abbeel a 'conscrit', while Abbeel was a proud volunteer. Abbeel admitted that he felt anxious, certainly because he didn't have any experience in fencing, but nevertheless he accepted the challenge and went outside. This was enough for Bonnaire who claimed that the challenge was only 'for fun'. Abbeel felt relieved, but Bonnaire didn't benefit from his joke because his comrades slapped him in the face and called him a coward. ${ }^{92}$

When Charles Parquin became brigadier of the Chasseurs à cheval and was only one month in function, a chasseur, a certain Hayer, called him a blanc-bec (greenhorn) immediately challenging him to 'try out' his saber against the saber of the challenger. Though higher in rank, Parquin didn't punish the soldier and accepted the challenge. Parquin thrusted his blade under the right arm of Hayer but got wounded at his foot..$^{93}$

Coignet entered the army in 1799 and became soldier of the $96^{\text {th }}$ demi-brigade de ligne. After being only two months in training, two drunkards approached him to challenge him for a duel; they wanted Coignet to take his saber because they wished to see "a drop of blood" and they asked him to chose his second. When Coignet replied that he didn't have a second, his master-at-arms (maître d'armes), who was probably the instigator of this challenge, was willing to take this place. Immediately the four men went to the garden to start the fight. Coignet stripped to his waist and placed himself en garde, provoking his opponent to deal the first blow. When his opponent refused to start, Coignet immediately began the fight...to be interrupted by his master-at-arms, saber in hand, who shouted: "Come on, embrace each other and let us drink a bottle of wine!" Surprised Coignet asked

\footnotetext{
90 Thiébault, Soldier of Napoleon, I, p. 39.

${ }^{91}$ Guillet, La mort en face, p. 99.

92 Abbeel, Met Napoleon naar Moskou, p. 13.

93 Parquin, Souvenirs, p. 48.
} 
his master the question if his opponent didn't want the drop of blood any more. The answer of his master ws very laconic: "It was just for fun!". Coignet added that the grenadier who wanted to kill him, later became one of his best friends. ${ }^{94}$

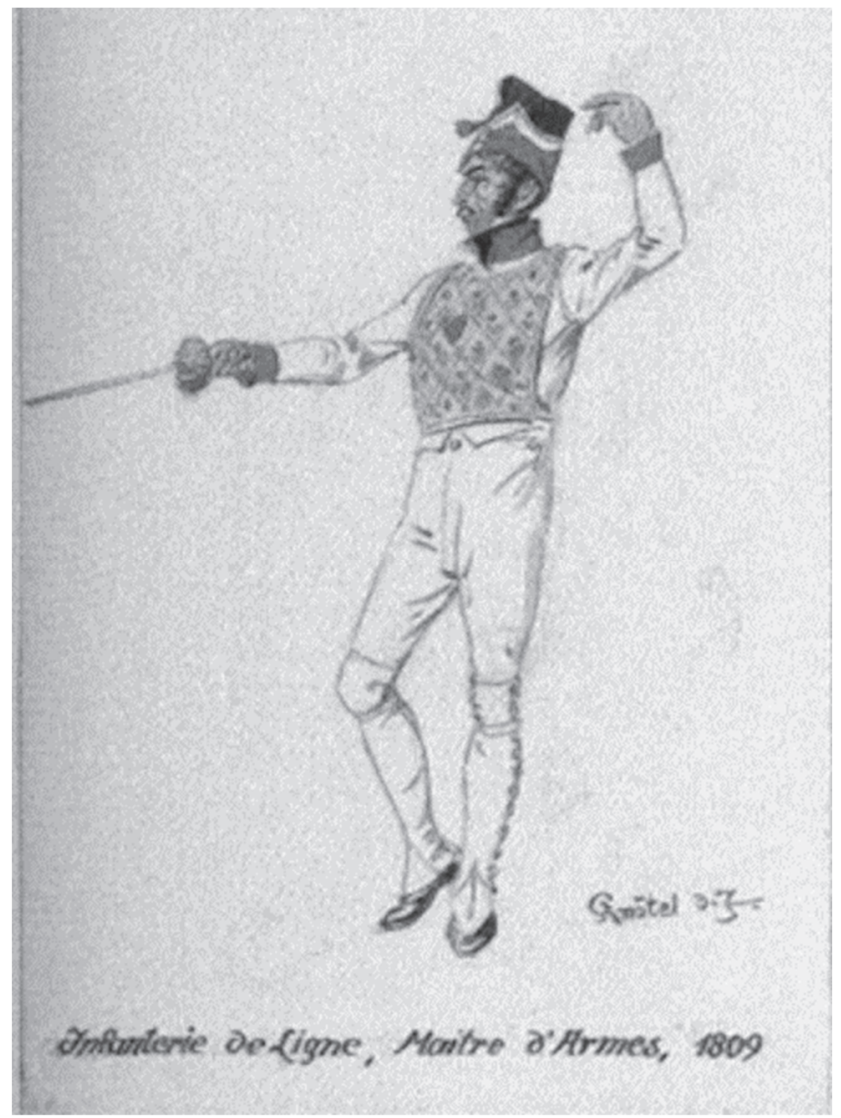

Figure 7: The master-at-arms around 1809 by Knötel

(John R. Elting, Napoleonic Uniforms, I, plate 19)

The duel of Coignet clearly shows how the master-at-arms could play a significant role in these duels as rite de passage. The maître-d'armes and his lieutenants, called prevots, were highly respected in the army. ${ }^{95}$ In Coignet's duel, he convinced others to challenge the young Coignet, but he could also seduce a young soldier to commit an act resulting in a duel. Upon seeing that a chasseur à cheval had left his shako on the ground, the master-at-arms of Henri Scheltens convinced his young apprentice (who was probably only 16 years old)

\footnotetext{
${ }^{94}$ Coignet, Cabiers, p. 87-88.
}

${ }^{95}$ Blaze, La vie militaire sous l'Empire, p. 289. For more information about the master-at-arms, see Gevaert, The use of the saber in the army of Napoleon, p. 124. 
to give the shako a hard kick. Scheltens was surprised by this request and remarked that doing so could provoke problems. His master replied that he didn't care about this, but that Scheltens had to start with something. Scheltens kicked the shako as hard as he could and - as expected - got 'rewarded' for his action with an even harder slap of the chasseur. There was no escape from a duel with sabers and both men met in the presence of about one hundred (!) people. Surprisingly Scheltens won the fight and received compliments of his master. Scheltens concluded that his master was the only responsible for the duel and the terrible wound (with possible disability) he caused his opponent. "But," Scheltens added, "if I would have refused to fight, my reputation would have been lost." "96

\section{VII.2. Duelling 'im Schimpf'}

Many duels simply started because the challenger was looking for a fight, not necessarily to hurt his opponent, but probably because he was looking for the thrill of a fight and the excitement of crossing blades. The reason to start the fight actually didn't matter, it was just a poor excuse to have some action.

When the young hussar Marbot was new in the cavalry, he was not so well aware that the point of his scabbard came in contact with the foot of a huge horse-gunner, who happened to sit with his legs sticking out. In a rude tone the artillerist shouted: 'Hussar, your saber drags too much!' Marbot tried to avoid the fight, but his mentor Pertelay convinced him to say: 'Come and lift it up then!' These words had the expected result and the gunner got up from his chair to fight... followed by all his comrades. From their side, the hussars protected Marbot and in the end, there was no duel. ${ }^{97}$

Some duellists wanted to teach a fellow soldier a lesson and only had the intention to cause a slight wound or scar - on the face - to remind their colleague of their mistake and the duel they had accepted or provoked. Sergeant Lacour only fought with quartermaster Jary (cfr. supra) to teach him modesty and that it was a serious mistake to challenge a superior fighter to duel. Lacour gave a feint to the leg of Jary and when the other went into parade to protect his leg, his opponent struck the other's face with the blade of his saber, not only causing a scar but also breaking the pipe of Jary. ${ }^{98}$

Certain people even had the reputation as duellists, because they constantly sought to cross blades with their fellow soldiers, usually after they had provoked a fight for the most futile reason.

One of these avid duellists was André Burthe (1772-1830) who rose to the rank of genéral de brigade and Baron of France. His friend Paul Thiébault writes:

\footnotetext{
96 Scheltens, Souvenirs d'un grenadier de la garde, pp. 21-22.

${ }^{97}$ Marbot, The young hussar, pp. 47-48.

98 Parquin, Souvenirs, p. 54.
} 
His life was shared between play, wine, duels and women, and yet he was not without merit, as he afterwards showed at Genoa. ${ }^{99}$

For Burthe duelling was a game and some days he even challenged several people to fight with him. He had a quarrel at the coffee-house with Colonel Dupuy of the 32nd Regiment and a bit later also with Major Dumoulin. Burthe probably didn't realize that Dupuy was one of the best fencers in France and that there was a huge chance that he could get killed by Dupuy. Dumoulin, on the other hand, was more on the same level of fencing as Burthe, so Thiébault, who acted as second, wanted his friend to fight with Dumoulin first. The idea was that Burthe could avoid the fight with Dupuy, after being wounded by Dumoulin. Both challengers of Burthe were eager to fight and immediately the fight with Dumoulin started, while Dupuy was watching. To his luck Burthe received a cut on the right hand and the duel stopped. For Dupuy and Dumoulin, this meant that there was no duel anymore... When the hand of Burthe was healed, he challenged Dumoulin again to duel and both men went to the Bois de Boulogne. Here they exchanged some pistol shots and Dumoulin made an apology... ${ }^{100}$

For Burthe duelling was a way of life and he enjoyed challenging others to fight with him. Others displayed behaviour which could provoke a duel but didn't take the fight seriously. A notorious example is general Antoine Charles Louis de Lasalle (1775-1809), who made love to the mistress of a captain of engineers. The captain challenged Lasalle to duel, which Lasalle gladly accepted. In the fight he didn't want to kill his opponent and only parried his blows, doing it with so much vigour that he broke the wrist of the engineer. When the engineer took a moment of rest, Lasalle

...would skip round him amid a thousand jokes, monkey-tricks and grimaces, giving him a spank behind with the flat of his sword, and go off in a burst of laughter. Ten times was this trick repeated, and, furious as the poor officer was, he was quite exhausted. ${ }^{101}$

Lasalle put an end to this unequal fight, calling his opponent a man of honour, nevertheless after having humiliated him for a long time in the duel.

Elzéar Blaze also remembers one of these 'natural born duellists': his prévôt, le sieur Dupré. As soldier of the infantry, Dupré hated horsemen and sought to cross blades with them. Once he approached a cuirassier who was drinking alone, took his glass, emptied it and started insulting the surprised man. When the cuirassier became angry and started shouting, Dupré proposed to arrange the matter 'entre Français'. Five minutes later the

99 Thiébault, Soldier of Napoleon, I, p. 295. Thiébault refers to the Siege of Genoa (6 April - 4 June 1800) where Burthe was wounded twice by musket balls.

100 Thiébault, Soldier of Napoleon, I, pp. 307-308.

101 Thiébault, Soldier of Napoleon, II, p. 78. 
cuirassier was dead. Even when Dupré was horribly wounded because of a duel and had to stay two months in hospital, his passion for duelling was still not over. ${ }^{102}$

\section{VII.3. Duelling 'im Ernst'}

In duelling no clear rules existed about the amount of (deadly) violence being used. It depended on the rage, intention or skill of the fighters if they wanted to hurt lightly, severely wound or even kill their opponent. Of course cutting was allowed, but - as mentioned before - no duellist protested when the more deadly thrust was used.

In his duel with Stoffel, Lejeune had two chances to kill his opponent. Twice he pinned his opponent against the wall, holding his right hand with his left hand, looking him in the eyes. Unwilling to kill his adversary, he uttered the words: "Must I?" After this Lejeune stopped the fight claiming that it had been enough for him, but in the meantime assuring that he was willing to fight again if his opponent would not be satisfied. ${ }^{103}$

Sometimes the hatred between two duellists was so strong that killing each other was the only intention, as in the duel between Chevillet and Cloès (cfr. supra). The anger of Cloès towards Chevillet was even intensified after a failed duel and a laughable fall of Cloès in the snow. Chevillet had another opponent, a certain Lacogrie, who also wanted to kill him, after Chevillet had beaten up his face with his bugle and had given him black eyes and a bloody nose. Lacogrie threatened Chevillet by saying: 'In one more hour, you won't be eating bread anymore'. Luckily for both men, they were separated by the adjutant and Lacogrie, who was seen as aggressor, was taken to the cell. ${ }^{104}$

It seems like Chevillet attracted deadly duels or that many men from his own regiment wanted to kill him in a duel, as a last example illustrates. When passing in a pine wood, Chevillet heared the cries of a German girl who was about to be raped by Moreau, one of Chevillet's comrades. Chevillet called what Moreau was wanting to do a 'despicable act', but these words didn't resort any effect on Moreau. Moreau even suggested his fellow chasseur to help him in achieving his goal so they could both take part of their trophy. For Chevillet this was enough, he called Moreau a coward and requested him to defend himself. With these words he 'officially' challenged Moreau to duel. Moreau accepted this challenge and without seconds or taking off their jackets, blades were crossed. After several blows, Moreau catched his foot on a tree stump and fell down. For Chevillet this was the moment to disarm his opponent, who told the winner that he now had the right to do as he liked and even kill him. Chevillet didn't want to kill his comrade and even said that he was ready to duel again the day after. Moreau admitted his mistake and for him the only explanation was that the devil had taken possession of him. Chevillet gave

102 Blaze, La vie militaire sous l'Empire, pp. 292-295.

103 Lejeune, The Napoleonic wars, I p. 107.

104 Chevillet, $A$ boy soldier in Napoleon's army, pp. 77-78. 
Moreau his saber back... and the girl? To the lucky and honourable man who saved her, she gave a kiss. ${ }^{105}$

\section{DEMI-SOLDES AND DUELLING FOR THE HONOUR OF FRANCE AND NAPOLEON}

After the first abdication of Napoleon in 1814 and his final fall in 1815, those soldiers who remained loyal to their emperor and didn't want to serve under the French king, were put on demi-solde. This meant that they only received half of their pension and very often they had a life suffering financial problems. Though they were poor, these men were proud defenders of the honour of the emperor.

The character of the demi-solde, hiding his former uniform under a long coat (redingote), walking stick in hand, became a very popular figure in art, literature, ${ }^{106}$ poetry ${ }^{107}$ and theatre. According to Frédéric Masson these men could be found in the area of the PalaisRoyal, looking for people who dared to insult the banished emperor. One of these duellists, an ancient colonel of the Imperial Guard, Barbier-Dufay, killed several men in this kind of duels. His most spectacular duel was fought on 27 July 1817 in a riding carriage, where he and his opponent were sitting, one hand tied to the back, the other armed with a big knife. When the carriage stopped, Barbier-Dufay left, covered with blood, but - by miracle - victorious! $!^{108}$

105 Chevillet, ibid, pp. 134-136.

${ }^{106}$ The most famous novel is probably Les demi-soldes, by Georges d'Esparbès (1898)

107 A fine example is the poem of François Coppée (1842-1908), Un duel au sabre (1904) in which a demi-solde avenges an insult against Napoleon, see: http://www.sabresempire.com/2012/03/unduel-au-sabreou-la-gloire-dun-demi.html (accessed 14 September 2018).

108 Guillet, La mort en face, p. 85, 153 and Jeanneney, Le duel, p. 113. 


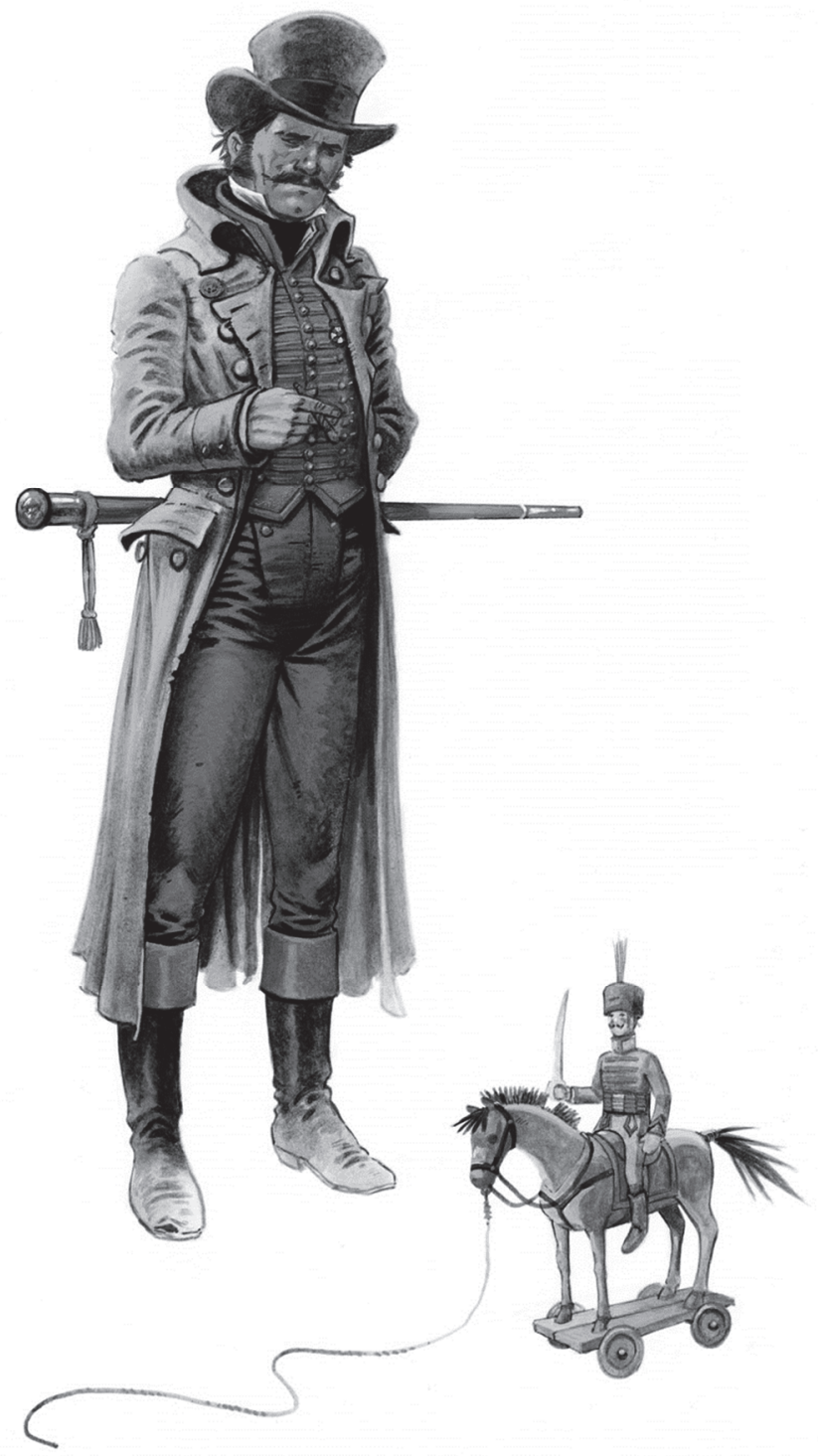

Figure 8: Démi-solde in his traditional outfit, an interpretation by Ken Broeders (2018) (Private Collection)

The favourite victims of the 'hunger for duelling' of the demi-soldes were royalists, persons wearing the fleur de lys (symbol of the royalists) or foreign soldiers doing their duty in 
France. ${ }^{109}$ Though there are no exact details known about specific duels he fought, Parquin had the reputation of being an avid and very successful demi-solde duellist. ${ }^{110}$ Another successful duellist was Colonel Constantin Denis Bourbaki (17871827) who was a proud wearer of the Légion d'Honneur. In 1821 he killed the royalist captain Lafitte in a duel, and one year later he was again involved in an anti-royalist duel. ${ }^{111}$

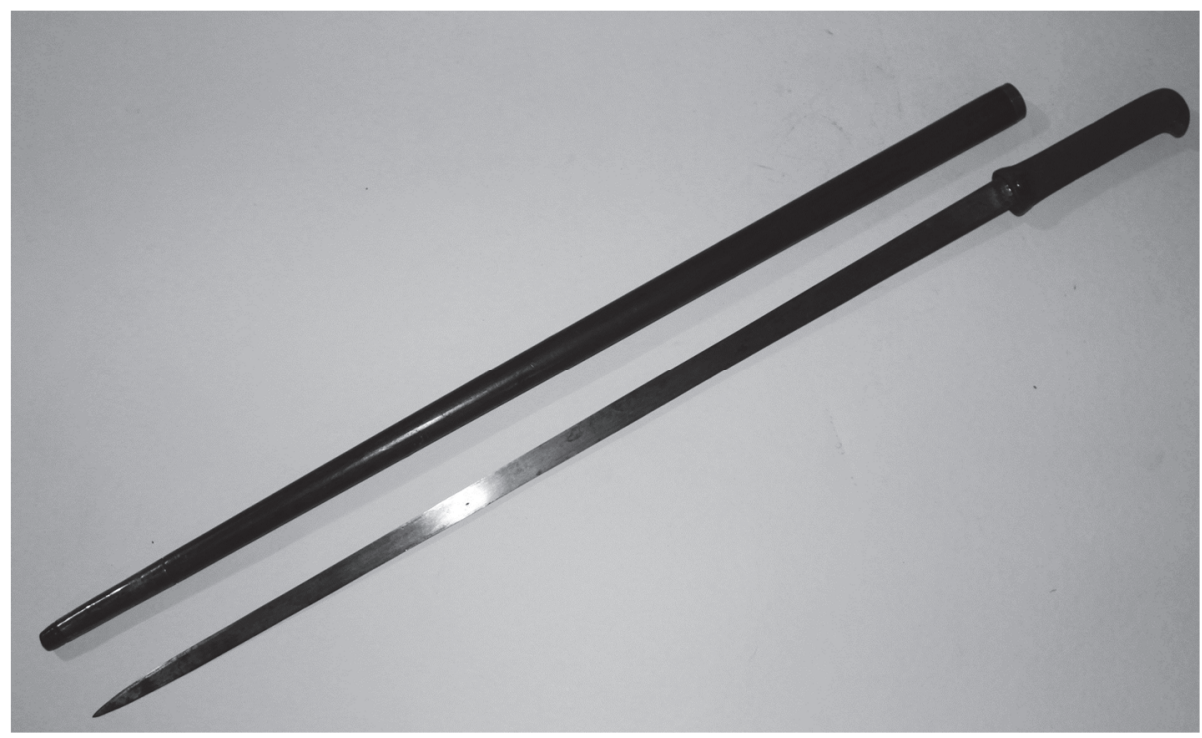

Figure 9: Canne-couteau or blade, bidden in walking stick. Many demi-soldes kept the blade of their old saber or smallsword, adjusted it to made it fit in a bollow walking stick. With this concealed weapon many duels were fought.

(Martial Arts Museum, Brescia)

Even soldiers who were not put on démi-solde and who served king Louis XVIII felt a terrible pain to see that foreign soldiers were walking freely in French cities, especially in Paris. Julien Combe and his friend Pascal fought many duels with Prussian and Russian officers, according to Combe not a week passed without a - sometimes - deadly duel. Once Combe fought with a Prussian officer who wanted to duel without using the point of the saber, but Combe told his opponent that in France duelling was a serious business, a matter of life or death and once the weapons in hand - on the condition that these weapons are used in a loyal way and with equal chances - you can fight according to your own dexterity and force. After these words and understanding that this fight could be

${ }^{109}$ Masson, Cavaliers de Napoleon, p. 285.

${ }^{110}$ Jourquin, Biographie du commandant Parquin, p. 388.

${ }^{111}$ Guillet, La mort en face, pp. 270-271. 
deadly, the Prussian officer was scared to death. Combe defeated him in less than two minutes, after tearing off the fake moustache of the Prussian! ${ }^{112}$

Usually these 'Waterloo duels', which lasted during the occupation of Paris (1815-1818) were fought to death between French soldiers and their Austrian, Russian and Prussian opponents. They served to avenge the wounded honour of French patriots against the humiliation of their country. ${ }^{113}$

Though never put on demi-solde, because he joined the banished Napoleon to Saint Helena, general Gaspar Gourgaud (1783-1852) is worth mentioning here. Gourgaud had a quarrelsome nature and even challenged Charles de Montholon (1783-1853) to duel when they were both on Saint Helena. The anger of Napoleon about this duel and the friction between Gourgaud and Montholon, combined with the boredom on Saint Helena, caused Gourgaud to leave the island of exile. Back in Europe, first England, then France, he strongly defended the case of the Emperor and put all his efforts in reclaiming the body of the dead emperor back to France. He also defended the honour of the emperor and that by all means. When lieutenant general Philippe de Ségur wrote his Histoire de Napoléon et de la Grande Armée en 1812 (Paris, 1824), which was critical about the emperor, Gourgaud challenged him to a duel and wounded him. ${ }^{114}$

\section{VICTIMS OF DUELLING}

In his duel with Stoffel both Lejeune and his opponent got lightly wounded, but without consequences and other soldiers didn't even notice that their comrades had been engaged in a duel.

This duel didn't have any influence on the military career of Lejeune, he even used the anecdote of the only duel in which he was involved to express his strong opinion against duelling (cfr. supra).

Other French duellists were less lucky, as in the case of Jerôme Bonaparte (1784-1860) who had to leave the consular guard of his famous brother, after he had been wounded in a duel by the younger brother of Nicolas Davout (1770-1823). ${ }^{115}$ Other duellists had

112 Combe, Mémoires du colonel Combe, pp. 278-280.

113 Athanassoglou-Kallmyer, Imago Belli, p. 275. English soldiers also fell in these duels. Jeanneney mentions a duel where a young English officer is shot dead after he missed his own shot. Before killing this young English soldier, his French opponent expressed that he felt sorry for the mother of the young man he was about to kill. After murmuring these words, he calmly aimed and killed without mercy. See Jeanneney, Le duel, pp. 175-176.

114 Macé, Le général Gourgaud, p. 27 (duel with Montholon) and p.215 (duel with Ségur)

115 Haythornthwaite and Courcelle, Napoleon's commanders 2, p. 11. 
to flee out of France, as 17-year old Pierre Daumesnil (1776-1832), who mortally wounded an artillerist in a duel. ${ }^{116}$

Duelling didn't cause Jerôme and Pierre to fail in their duties to France, but others could not participate in battles because of duelling wounds. Philip-Antoine d'Ornano missed the Battle of Waterloo (18 June 1815) because defending his honour was more important than fighting for the Emperor... ${ }^{117}$

In the $5^{\text {th }}$ Hussars regiment, between 1796 and 1813, about 19 soldiers and sub officers were unable to fight as a consequence of duelling. Between 1793 and 1810 duelling caused the death of 11 members of this regiment. ${ }^{118}$

Fantin Des Odoards (1778-1866) complains that about fifty soldiers of his regiment had died because of duelling, which he calls 'ce préjugé déplorable qu'on décore du nom de pointd'honneur' (this deplorable prejudice, decorated with the name point of honour) ${ }^{119}$ Paul Thiébault mentions how the French Army of Italy, after the Treaty of Leoben (18 April 1797) nicknamed the Army of the Rhine, under command of Bernadotte (1763-1844), the 'gentlemen's' army because in their opinion they didn't have any experience in battle. In the absence of general Massena the soldiers of the Rhine started numerous duels resulting in more than a hundred victims in the division of Bernadotte and about sixty in their own group. At a certain point the animosity between the two armies was so high that they were at the point of charging each other with the bayonet! The risk of a huge duel was only taken away by forcing the Army of Italy to march before daybreak and getting out of sight of the Army of the Rhine. ${ }^{120}$

The famous surgeon Dominique Jean Larrey (1776-1842) describes several cases of soldiers whom he treated after they had fought in duels. ${ }^{121}$ One soldier had his forearm amputated because Larrey feared the soldier would get infected with gangrene. ${ }^{122}$ In one case Larrey dedicated several pages to describe the treatment and healing process of the arm wound of Pierre Cadrieux, who was injured in a duel. Not one bad word is said about the origin of the wound. Larrey even seems enthusiastic to describe the complex arm

116 Chasseurs à cheval of Napoleon's guard, p. 23.

117 Haythornthwaite and Courcelle, Napoleon's commanders 2, p. 27. For a description of this duel, fought with pistols, see Norris, Pistols at dawn, pp. 35-36.

118 Massoni, Histoire d'un régiment de cavalerie légère, p. 229.

${ }^{119}$ Fantin Des Odoards, Journal du général Fantin Des Odoards, p. 100.

120 Thiébault, Soldier of Napoleon, I, p. 295.

${ }^{121}$ For Larrey dealing with wounds after duels with pistols, see Norris, Pistols at dawn, pp. 139-140.

${ }^{122}$ Larrey, Mémoires de chirurgie militaire et campagnes, p. 455. 
wound and how he could heal it. He even used the wound of Cadrieux and the healing process as an interesting case in the Medical School of Paris. ${ }^{123}$

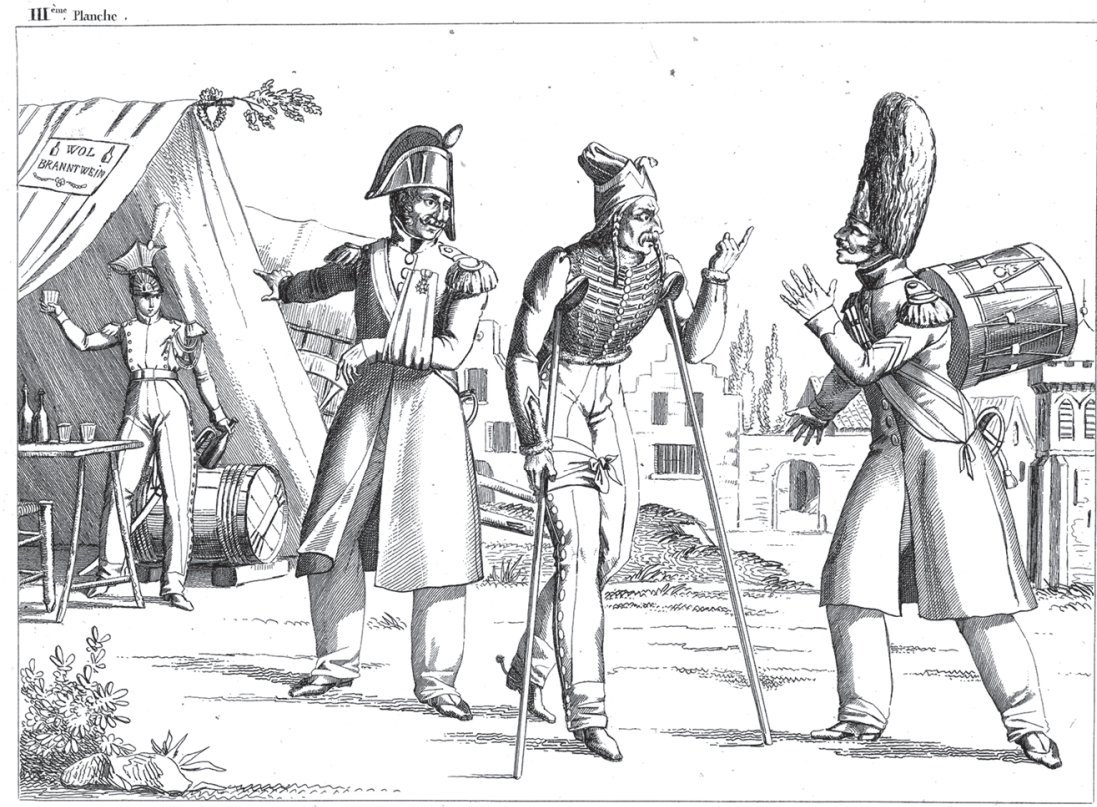

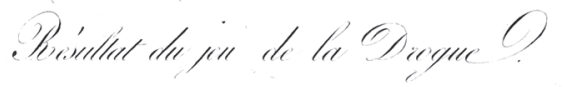

Figure 10: Résultat du jeu de la Drogue, by C. de Last after Horace Vernet (1818)

On this image the results of a duel, as consequence of La Drogue (see figure 2), can be seen: wounded soldiers.

(Bibliothèque Nationale de France, Paris)

The duel with Hayer caused a very serious wound to the foot of Parquin: he had to stay about six weeks in the military hospital! Parquin comments that he was saved by his very young age and the 'purity of his blood', otherwise his foot would have been amputated and he would have been crippled for the rest of his life. ${ }^{124}$

General Destaing is a sad example, proving that not only common soldiers and sub officers died in duels. He was killed by J.E. Reynier in $1802 .{ }^{125}$

123 Ibid., pp. 896-901.

124 Parquin, Souvenirs, p. 48.

125 Haythornthwaite and Courcelle, Napoleon's commanders 2, p. 51. 


\section{AN EXPLANATION}

It can't be denied that alcohol and gambling (e.g. La Drogue, see figure 2 and 10) had an important triggering effect to cause soldiers to draw their weapons and start a duel. ${ }^{126} \mathrm{Of}$ course, group pressure also played a significant role and maybe some soldiers used the duel as a tool to get rid of a personal enemy. In this way, they could 'legally' kill a person, instead of murdering him in cold blood.

For most soldiers defending their honour was probably one of the main reasons to draw a weapon, but it can't be denied that 'hidden' reasons also existed such as boredom and maybe a concealed wish to die. A combination of these three reasons can be found in the duels fought by the démi-soldes: because they lost their privilege as a soldier of the emperor, they had also lost their honour. Not being soldiers anymore, they were probably bored and duelling made them live again. Maybe every duel they engaged in was a possible suicide, a possible escape from a life without honour, without emperor, without purpose?

\section{X.1. Boredom}

Though there are some notable examples, most duels happened in the military schools or when soldiers were not directly involved in war. Clear examples can be found in the writings of Octave Levavasseur, who mentions two moments during his military career when there was plenty of time to duel. When he was a student at the military academy of Metz (Ecole d'application de l'artillerie et du génie), his days were divided between studying, going to the pub, to the riding academy or to the fencing room.

One only heard talking about broken windows, strangled cats, dogs pierced through and through. Duels without compromise were the rule and the saber was the common law. The encounters took place on every moment, on broad daylight: for one word, one was ready to battle. ${ }^{127}$

From 1803 till 1805 a huge army was assembled near Boulogne-sur-mer in France. Here this army prepared for the big invasion of England and already in September 1803 about 114,000 men were gathered for a massive military operation. Life in the barracks, which resembled prison cells, was boring and between exercises, many soldiers found a moment of relief in the arms of prostitutes. Soldiers went to pubs, drank too much, insulted townspeople, harassed women, played games and veterans tested new soldiers. With many weapons at hand, duelling was an easy way to experience the risks of the far away battlefield. ${ }^{128}$

Levavasseur was also at the Camp de Boulogne and as so many soldiers, he was bored to death. According to him, duelling was a daily issue and usually the master-at-arms was the

\footnotetext{
126 Norris, Pistols at dawn, p. 24.

127 Levavasseur, Souvenirs militaires, p. 3.

128 Blond, La Grande Armée, pp 13-17.
} 
judge. Soldiers from different regiments fought and when one was defeated, the masterat-arms chose a new soldier to avenge his wounded comrade. At a certain moment these duels caused so many victims that the general commander had to remember the soldiers about their duty to save their courage for the enemy. The commander claimed that every soldier was a brave man and that they didn't have to prove this. Levavasseur was assigned to deliver this message to the men, but the words of the commander didn't have any results. Soldiers kept on duelling until the departure to Germany. ${ }^{129}$

The same boredom can also be found in the many duels, fought out by démi-soldes, who saw the duel as a surrogate for the military action they had missed for so many years in combination with a quest for honour and an evocation of a glorious past. ${ }^{130}$

In the comedy of Léon Halély, Le duel, a retired general of the Empire mentions the death of his brother in a duel:

There was no more war;

Duels were his only comfort...

He was bored! It's like me!131

\section{X.2. Escaping the terrors of war and concealed suicide? 132}

French soldiers in prison hulks fighting to the death were not only fighting against the boring existence of a prison life. It is very well possible that death in a duel was an honourable way of escaping from the terrors of living in an overcrowded, stinking ship, where food was scarce and death of starvation omnipresent.

But also on land and not in prison, life could be hard for soldiers. Some of them, the conscrits, were forced to enter the army, forced to fight against opponents they didn't know for a cause they were not familiar with. Since many of these conscrits came from catholic countries where suicide was strictly forbidden by the church, duelling could be a possible escape from the 'vale of tears', which was the army and all its terrors in their eyes. In this way, it can be explained why many conscrits picked up the sword when they were as challenged to duel against a veteran as young recruits.

One of the longest descriptions of duels and duellists can be found in the writings of Parquin, who speaks about the already mentioned Léopold Himonet. Not only Parquin fought with Himonet (and wounded him), but many other soldiers crossed blades with Himonet. Himonet was always ready to fight and seemed to find a certain pleasure in insulting fellow soldiers, resulting in a duel. Even when Parquin warned Himonet not to fight with Auguste Fage, who was a very good fencer, he ignored the advice... and

${ }^{129}$ Levavasseur, Souvenirs militaires, pp. 19-20.

130 Athanassoglou-Kallmyer, Imago Belli, p. 275.

${ }^{131}$ Cited by Athanassoglou-Kallmyer, Imago Belli, p. 275.

${ }^{132}$ Guillet, La mort en face, p. 116. 
afterwards Parquin saw him with a wounded arm. Himonet always had bad luck in duels and his comrades used to call him 'Easy' (facile) 'to kill'. Himonet was a bad fencer and didn't know how to protect himself and was - according to Parquin - always the first to be wounded. But still, Himonet kept on challenging others to duel, even when he became captain in 1813. In 1823 Himonet challenged his last opponent and was killed by a pistol. ${ }^{133}$

\section{X.3. Defending honour and quest for honour}

For the majority of the French officers (and soldiers) - with the notable exception of Lejeune (cfr. supra)! - there was no distinction between honour displayed on the battlefield and honour displayed in a duel. For this reason certain officers were even punished because they refused to duel after a legitimate challenge. ${ }^{134}$

Several French soldiers explicitly state that they duelled to defend their honour and that, once their honour threatened, there was no other choice than to cross blades:

An officer can not, may not accept any insult, not even a form of rudeness. The duel inspires to have respect and many times it folds characters to moderation. I have seen men who, because of their character, are willing to make a lot of noise, are bashers and even more; but when they were standing in front of a sword, they were cowards. Civilians can react as they see right, but an officer who lacks courage, has to be considered a dead man by his comrades; he is not worthy anymore to wear the epaulettes or the officer's spadroon. ${ }^{135}$

These strong words of Scheltens leave no doubt: an officer has to defend his honour, even if it can cost him his life. Duelling shows the true nature of a man and refusing to duel is only a sign of being a coward. Especially soldiers have the duty to defend their violated honour by the use of violence in the way of duelling. Notice that Scheltens explicitly refers to the comrades of the officer, it is they who declare the person who refuses to duel to be a coward. Peer pressure in defending your honour could certainly not be underestimated!

On the other hand, duelling provided the combatant with the ability to look his adversary in the face and to fight man-to-man, which was usually not possible on the battlefield. Since the use of gunpowder, war had become more and more impersonal. ${ }^{136}$ Smoke of muskets, carbines and cannons clouded the battlefields and the sound of the same weapons deafened soldiers. A cannon, nicknamed by Napoleon's soldiers as 'le brutal,

\footnotetext{
133 Parquin, Souvenirs, pp. 223-225 and p. 228.

${ }^{134}$ Nye, Mascullinity and male codes of honor, p. 132.

135 Scheltens, Souvenirs d'un grenadier de la garde, p. 133.

${ }^{136}$ Guillet, La mort en face, p. 114.
} 
vomited bullets and canister, coming out of nowhere and killing several soldiers with one single shot. Soldiers using these weapons could kill their opponents without even seeing their face or the results of what they had fired. A small piece of lead could kill the most experienced swordsman, as happened to Lasalle during the Battle of Wagram (5-6 July 1809). ${ }^{137}$ While charging the enemy, he was shot between the eyes and died instantly. ${ }^{138}$

Duelling gave a face to the opponent and made war more personal, heroic, and Homeric.

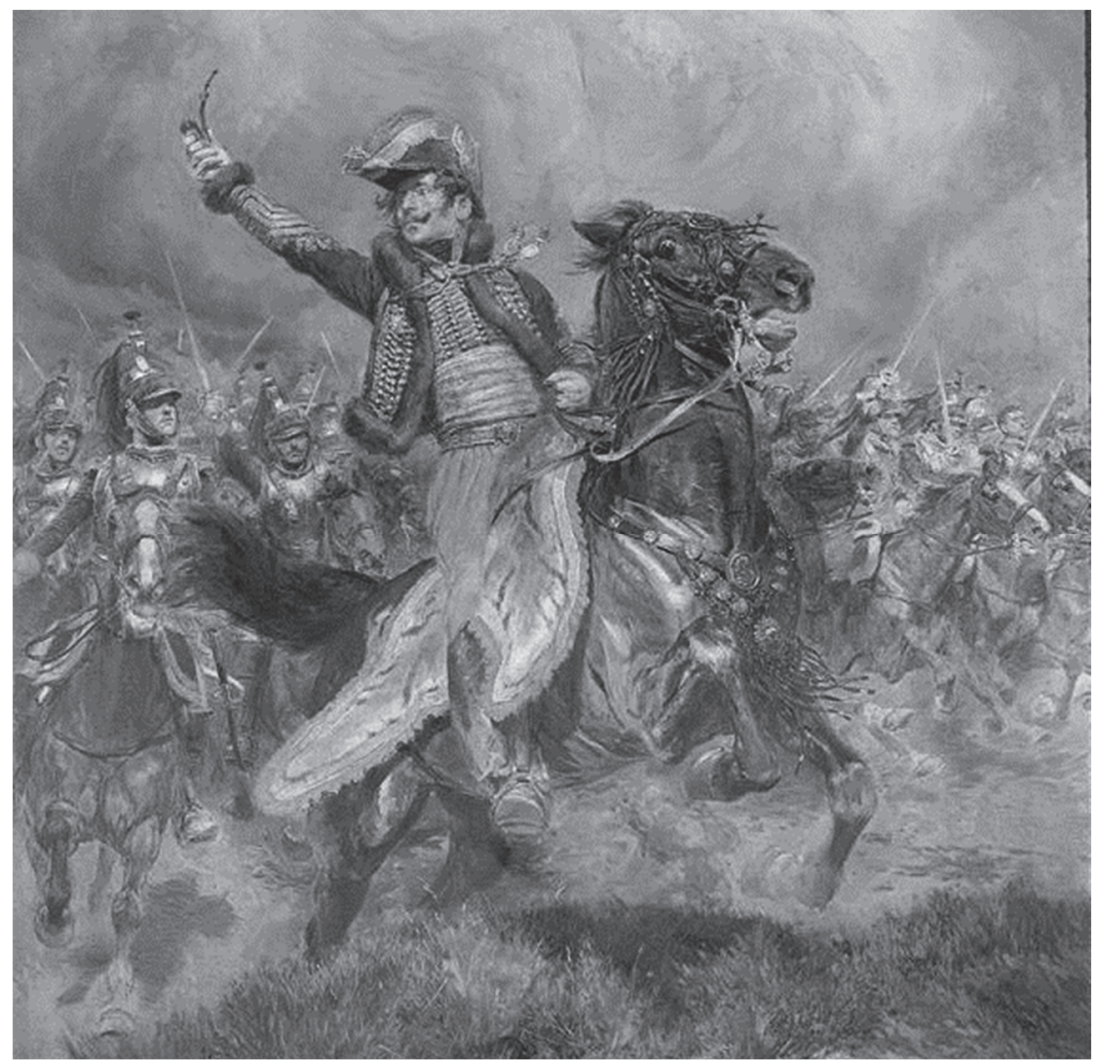

Figure: La dernière charge de general Lasalle, tué à Wagram, le 6 juillet 1809 (1912)

Paris, Musée de l'Armée.

${ }^{137}$ For more (medieval and renaissance) complaints about the use gunpowder in warfare and how gunpowder destroyed the art of war, see Gevaert, Te Wapen, p. 179.

138 Aude, Le général Antoine-Charles-Louis de Lasalle, pp. 103-105. 


\section{BIBLIOGRAPHY}

\section{XI.1. Primary sources and critical editions of primary sources}

Elzéar Blaze, Captain Blaze: Life in Napoleon's army, ed. and trans. by Charles James Napier (London: Leonaur Ltd, 2007).

Elzéar Blaze, La vie militaire sous l'Empire, ou mours de la garnison, du bivonac et de la caserne, vol. I (Paris: Moutardier et Desforges, 1837).

Jacques Chevillet, $A$ boy soldier in Napoleon's army: the military life of Jacques chevillet, $8^{\text {th }}$ regiment of Chasseurs à Cheval, 1800-1810, edited and translated by Thomas Cardoza (New Napoleonic Memoirs) (North Charleston: CreateSpace Independent Publishing Platform, 2017).

Julien Combe, Mémoires du colonel Combe sur les campagnes de Russie, 1812, de Saxe, 1813, de France, 1814 et 1815 (Paris: Blot, 1853).

Jean-Roch Coignet, Cabiers du capitaine Coignet (Paris: Arléa, 2012).

Jean-Roch Coignet, Les cabiers du capitaine Coignet (1799-1815) publiés par Lorédan Larchey, d'après le manuscrit original avec gravures et autographe fac-similé, ed. by Lorédan Larchey (Paris: Librairie Hachette et Compagnie, 1883).

Victor Dupuy, Souvenirs militaires de Victor Dupuy, chef d'escadrons de Hussards: 1794-1816, publies, avec une préface, par le général Thoumas (Paris: C. Lévy, 1892).

Hippolyte d'Espinchal, Souvenirs militaires, 1792-1814 (Tome 2), publié par Frédéric Masson et François Boyer (Paris: Ollendorff, 1901).

Louis Florimond Fantin des Odoards, Journal du général Fantin Des Odoards, étapes d'un officier de la Grande Armée, 1800-1830 (Paris: Plon-Nourrit, 1895).

Dominique Larrey, Mémoires de chirurgie militaire et campagnes, I (1787-1811: Campagnes de l'Amérique Septentrionale, du Rhin, de Corse, des Alpes-Maritimes, de Catalogne, d'Italie, d'Egypte et de Syrie, de Boulogne, d'Ulm et d'Austerlity, de Saxe, de Prusse, de Pologne, d'Espagne et d'Autriche avec planches (Bibliothèque Napoléonienne) (Paris: Tallendier Editions, 2004).

Dominique Larrey, Mémoires de chirurgie militaire et campagnes, II (Campagnes de Russie, de Saxe, et de France, relation Médicale de campagnes et voyages, annexes avec planches (Bibliothèque Napoléonienne) (Paris: Tallendier Editions, 2004).

Louis-François Lejeune, The Napoleonic wars through the experiences of an officer on Berthier's staff ( 2 vols), ed. and trans. by Arthur Bell (London: Leonaur Ltd, 2007).

Octave Levavasseur, Un officier d'état-major sous le premier Empire. Souvenirs militaires d'Octave Levavasseur, officier d'artillerie, aide de camp du maréchal Ney (1802-1815), ed. Pierre Beslay (Paris: Librairie Plon-Nourrit, 1914).

Jean Baptiste Antoine Marcellin de Marbot, The memoirs of Baron de Late, ed. by Arthur John Butler (London: Forgotten Books, 2013). 
Jean Baptiste Antoine Marcellin de Marbot, The life of the real 'Brigadier Gerard', The young bussar, volume 1, 1782-1807: a French cavalryman of the napoleonic wars at Marengo, Austerlits, Jena, Eylau and Friedland, ed. and trans. by Arthur John Butler (Londen: Leonaur Ltd, 2006).

Jean Baptiste Antoine Marcellin de Marbot, The life of the real 'Brigadier Gerard', Imperial Aide-de-Camp, volume 2, 1807-1811: a French cavalyman of the napoleonic wars at Saragossa, Landshut, Eckmubl, Ratisbon, Aspern-Essling, Wagram, Busaco and Torres Vedras, ed. and trans. by Arthur John Butler (Londen: Leonaur Ltd, 2006).

Denis Charles Parquin, Souvenirs (1803-1814) et biographie du commandant Parquin (18151845), officier et consiprateur, edited and commented by Jacques Jourquin (Bibliothèque Napoléonienne) (Paris: Tallendier Editions, 2003).

Denis Charles Parquin, Récits de guerre: Souvenirs du capitaine Parquin 1803-1814 (Paris: Boussod, Valadon et Compagnie, 1842, repr. 1892).

Henri Scheltens, Souvenirs d'un grenadier de la Garde (Paris: Bernard Giovangeli Editeur, 2014).

Louis Rilliet, Journal d'un sous-lieutenant de cuirassiers 1810-1814, présenté et annoté par Olivier Lapray (Editions du Grenadier), ed. by Olivier Lapray (Paris: Bernard Giovanangeli Editeur, 2013).

Paul Thiébault, Soldier of Napoleon, a personal account of the revolutionary wars and conflicts of the French First Empire (2 vols), ed. and trans. by Arthur John Butler (London: Leonaur Ltd, 2014).

\section{XI.2. Secondary literature}

Athanassoglou-Kallmyer, Nina N., 'Imago Belli: Horace Vernet's L'Atelier as an image of radical militarism under the Restoration', The Art Bulletin 68 (2) (1986) 268-280.

Atteridge, Hilliard A., Marshal Ney: The bravest of the brave (Barnsley: Pen and Sword Military, 2005).

Aude, Nicolas, Le général Antoine-Charles-Lonis de Lasalle (1775-1809), l'héritage d'une légende (Paris: Bernard Giovangeli Editeur, 2018).

Blond, Georges (transl. Marshall May), La Grande Armée (Edison: Castle Books, 2005).

Briost, Pascal., Hervé Drévillon and Pierre Serna, Croiser le fer. Violence et culture de l'épée dans la France moderne (XVIe-XVIIIe siècle) (Les Classiques de Champ V allon) (Seyssel: Champ Vallon, 2002).

Cohen, Richard, By the sword: gladiators, musketeers, samurai, swashbucklers, and Olympic champions (London: Simon and Schuster UK Ltd, 2010).

Crowdy, Terry E., Napoleon's infantry handbook (Barnsley: Pen and Sword Military, 2015).

Elting, John. R. (text) and Herbert Knötel (ill.), Napoleonic uniforms, vol. I. (London: Macmillan,1993) 
Elting, John.R., Swords around a throne: Napoleon's Grande Armée (New York: Da Capo Press, 1988, repr. 1997).

Esparbès, Georges d', Les demi-soldes, roman épique (Paris: Flammarion, 1898).

Gevaert, Bert, Te wapen! Europa's vergeten krijgskunsten (Leuven: Davidsfonds, 2016)

Gevaert, Bert, The use of the saber in the army of Napoleon, Acta Periodica Duellatorum, Scholarly volume, 4/1 (2016), 103-151.

Groos, Anne-Isabelle, 'duel' in Jean Tulard (ed.), Dictionnaire Napoléon (Paris: Arthème Fayard, 1987) pp. 625-626.

Guillet, François, La mort en face: histoire de duel de la Révolution à nos jours (Aubier: Collection historique) (Paris: Flammarion, 2008).

Haythornthwaite, Philip (text) and Patrice Courcelle (Illustrations), Napoleon's commanders (1) c. 1809-15 (Osprey Elite 72) (Oxford: Osprey Publishing, 2001).

Haythornthwaite, Philip (text) and Patrice Courcelle (Illustrations), Napoleon's commanders (2) c. 1809-15 (Osprey Elite 83) (Oxford: Osprey Publishing, 2002).

Jeanneney, Jean-Noël, Le duel: une passion française (1789-1914) (Collection Tempus) (Paris: Editions Perrin).

Loades, Mike, Swords and swordsmen (Barnsley: Pen and Sword Military, 2010).

Macé, Jacques, Le général Gourgand (La Bibliothèque Napoleon) (Paris: Nouveau Monde Editions, 2006).

Masson, Frédéric, Cavaliers de Napoléon (Paris: Albin Michel,s.d. ).

Massoni, Gérard-Antoine, Histoire d'un régiment de cavalerie légère: le 5e hussards 1783-1815 (Paris: Archives \& Culture, 2008).

Norris, John, Pistols at dawn: a history of duelling (Stroud: The History Press, 2009).

Nye, Robert A., Masculinity and male codes of honor in modern France (Berkely, Los Angeles and London: University of California Press, 1993).

Pigeard, Alain, 'duel' in Alain Pigeard (ed.), Dictionnaire de la Grande Armée (Bibliotheque Napoléonienne) (Paris: Tallendier Editions, 2002) pp. 227-228.

Sobocinski, Carl, 'Celebrating historical accuracy in The Duellists' in Adam Barkman, Ashley Barkman and Nancy Kang (eds), The culture and philosophy of Ridley Scott (Plymouth, UK: Lexington Books, 2013) pp. 171-180. 
The evolution of German Cut Fencing in the $19^{\text {th }}$ century viewed through the works of Friedrich August Wilhelm Ludwig Roux

\author{
Alex Kiermayer \\ Ochs historische Kampfkünste e.V.
}

Abstract-This article takes a look at the characteristics of German civilian fencing with cutting swords in the $19^{\text {th }}$ century, especially the style taught by the Roux family of fencing masters. One of the most prominent members of this family was Friedrich August Wilhelm Ludwig Roux. By comparing his early work Anweisung zum Hiebfechten mit graden und krummen Klingen and his later work Deutsches Paukbuch one is able to discern some of the changes in German Hiebfechten or fencing with cutting weapons during the $19^{\text {th }}$ century, in particular on the students' duelling ground.

Context - Fencing in $19^{\text {th }}$ century Germany was practiced for a number of different reasons. These included military service, physical education and the civilian duel. A particular form of the civilian duel in Germany was the student's Mensur. The works of the Roux family naturally revolve mostly but not exclusively around this subject as most of them were employed as University fencing masters. In the military and in physical education the contemporary method of the "Berliner Turnschule" was more popular.



Fig. 1 - Sabre Mensur scene 


\section{THE ROUX DYNASTY OF FENCING MASTERS ${ }^{1}$}

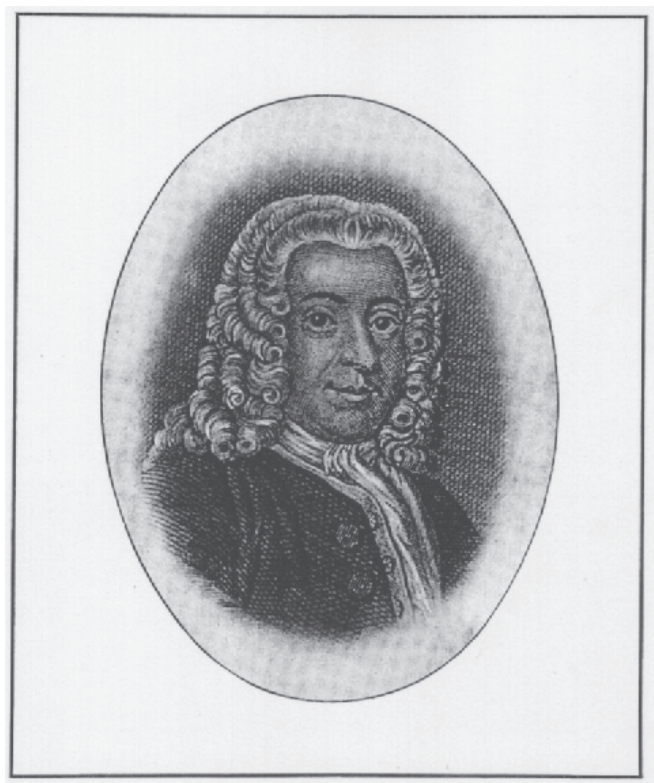

Fig. 2 - Francois Roux

Francois Roux, a French Huguenot and son of count Louis Roux (09.05.1674 07.03.1750), immigrated to Saxony-Weimar and eventually became lector for the French and Italian language at the university in Jena in the year 1709. ${ }^{2}$ His son Heinrich Friedrich Roux (23.11.1728 - 16.03.1791 in Jena) developed a talent for fencing and became provost at the Kreussler fencing salle in Jena under the tutelage of Johann Wolfgang Bieglein-Kreussler. After the death of Bieglein-Kreussler he took over the Kreussler salle and managed it together with his collegue Johann Heinrich von den Brinken. Heinrich Friedrich wrote several books, including a very popular French-German dictionary and the fencing manual Versuch über das Contrefechten auf die rechte und die linke Hand.

${ }^{1}$ The information in this chapter is mainly drawn from "Die Fechtmeisterfamilien Kreußler und Roux" by Paul Roux and http://www.ahnen.roux.de/

2 Dahmen, Wolfgang, "Gebrauchsgrammatike" und "Gelebrte Grammatik." französische Spracblebre und Grammatikographie zipischen Maas und Rhein vom 16. Bis zum 19. Jabrbundert, pp. 210 (Gunter Narr Verlag, 2011) 


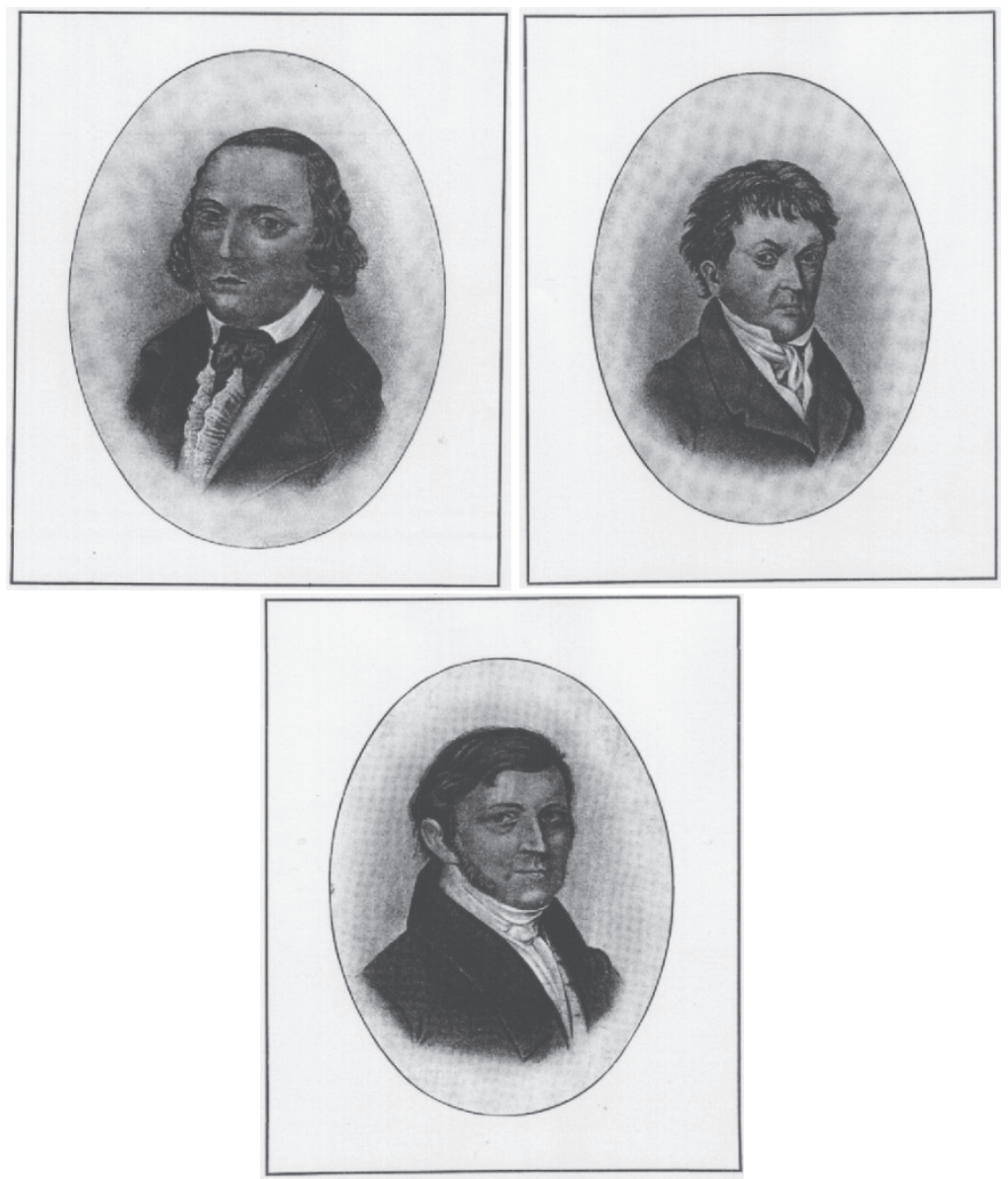

Fig. 3 - Johann Friedrich Gottried Roux

Fig. 4 - Johann Adolph Karl Roux

Fig. 5-Johann Wilhelm Roux

Heinrich Friedrich Roux had three sons who also became fencing masters. Johann Friedrich Gottfried Roux (08.05.1760 in Jena - 1828 in Tübingen) was fencing master in Tübingen from 1794 - 1821. Dr. Johann Adolph Karl Roux (25.10.1766 in Jena 07.01.1838 in Erlangen) taught fencing in Jena and from 10.12.1799 onwards in Erlangen. There he founded the first institution for physical exercise at a German university in 1806. He wrote Anweisung über das Hiebfechten. Often the book Gründliche und vollständige Anweisung in der deutschen Fecht-Kunst is also attributed to him. This attribution is questionable for several reasons that will not be addressed here. Dr. math. Johann Wilhelm Roux (17.09.1777 in Jena - 01.04.1840 in Meiningen) became fencing master and teacher of mathematics and physics at the courtly institute of Gotha. He wrote Anleitung zur Fechtkunst nach mathematisch-physikalischen Grundsätzen. 
Johann Wilhelm's son Friedrich August Wilhelm Ludwig Roux (20.05.1817 - 02.06.1897 in Jena) became university fencing master in Jena in 1839. He was instrumental in switching from the Stosscomment (rules for the students' duels with thrusting weapons) to the Hiebcomment (rules for duelling allowing only cutting weapons), but more on that later. He authored Anweisung zum Hiebfecbten mit graden und krummen Klingen, Deutsches Paukbuch and Die Kreussler'sche Stossfechtscbule.



Fig. 6 - Ludwig Caesar Roux

Ludwig Caesar Roux (27.06.1843 in Jena - 20.05.1913 in Leipzig) was the son of F. A. W. L. Roux. In 1865 he became university fencing master in Leipzig. He popularized his father's method and became one of the founding members of the Verein Deutscher Fechtmeister that was constituted on the $20^{\text {th }}$ of August 1884 in Frankfurt am Main. His book Die Hiebfechtkunst was published in three editions and formed the basis for academical fencing all over Germany. In it he systematized his father's new method.

Ludwig Caesar's son Paul Roux (26.05.1870 - 28.10.1935 in Leipzig) became university fencing master in Leipzig in 1902. He was author of two books: Das Säbelfechten and Die Fechtmeisterfamilien Kreußler und Roux. 


\section{FRIEDRICH AUGUST WILHELM LUDWIG ROUX}

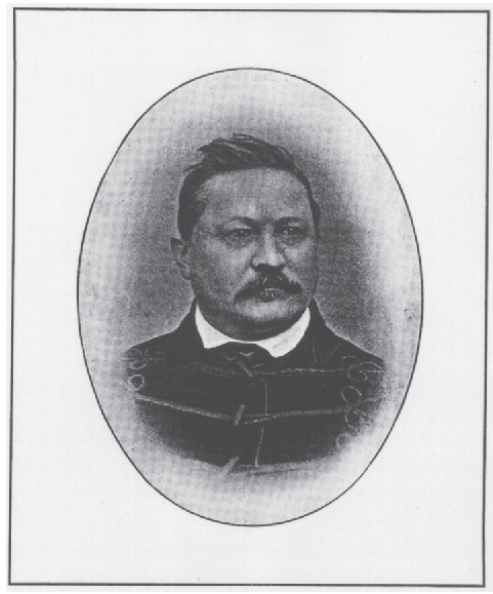

Fig. 7 - Friedrich August Wilhelm Ludwig Roux

Friedrich August Wilhelm Ludwig Roux was the seventh of ten children of Johann Wilhelm Roux and his wife Luise Christiane Wilhelmine, née Hennings. He continued the family tradition of Kreusslerian thrust fencing but became more and more an advocate of cut fencing. F.A.W.L. was employed as fencing master by the University of Jena on the $1{ }^{\text {st }}$ of July 1839 in order to introduce the Hiebcomment. ${ }^{3}$ Following several cases of deaths resulting from students' duels (Mensuren) he and his friend Karl Hermann Scheidler worked hard to replace the old thrust fencing on the student's duelling grounds with the less lethal cut fencing and make the students' duels safer. ${ }^{4}$ On the $16^{\text {th }}$ of November 1840 the Senate of Jena declared that duels with thrust-weapons will henceforth be prosecuted as a criminal offense. ${ }^{5}$

Friedrich August Wilhelm Ludwig finished and published his uncle's book Über das Verbältnis der deutschen Fechtkunst zum Ehrenduell sowobl im allgemeinen, als auch für Universitäten insbesondere mit Berücksichtigung der Mittel, die Duelle zu verbüten, oder sie wenigstens unschädlich zu

3 Roux, Paul, Die Fechtmeisterfamilien Kreussler und Roux: ein geschichtlicher Rü̈kblick auf die deutsche Fechtkunst vom Mittelalter bis zum Anfang des gegenwätigen Jahrbunderts, p. 21/22, 33ff. (Jena: Frommannsche Buchdruckerei, 1911?)

${ }^{4}$ Scheidler in: Roux, Friedrich August Wilhelm Ludwig - Scheidler, Karl Hermann, Anweisung zum Hiebfechten mit graden und krummen Klingen (Jena: Verlag von Friedrich Mauke, 1840), p. 53: "In der Erlernung der Hiebfechtkunst und der allgemeinen Einführung des Hiebcomments liegt nun eben jenes gesuchte Mittel, die Duelle möglichst zu vermindern und möglichst gefabrlos zu machen.”

${ }^{5}$ Henner, Die Entwicklung des Fechtens an deutschen Hochschulen, Historia Academica - Heft 5 (Stuttgart: Verlag Heinrich Fink GmbH + Co., 1983), p. 54; Scheidler, Karl Hermann, Ueber das deutsche Studentenleben und die Nothwendigkeit einer innern, von den Studirenden selbst ausgehenden Reform desselben, (Jena: Bran'sche Buchhandlung, 1842), p. 64 
machen und zu mindern. But he was a prolific writer by himself: In addition to his book on thrust fencing F. A. W. L. Roux wrote two books on cut fencing, both including the straight-bladed Schläger and the curved-bladed sabre. The first one, Anweisung zum Hiebfechten für grade und krumme Klingen was published in 1843, and the second one, Deutsches Paukbuch, fourteen years later in 1857. By comparing these books one can discern a vast change in the techniques shown.

\section{THE WEAPONS USED}

Hiebfechten in Germany was conducted with both straight-bladed and curved-bladed swords. In the $19^{\text {th }}$ century the German term for the straight-bladed weapon was Degen, while the curved bladed weapon was called $S a ̈ b e l$. But terminology gets complicated when you delve deeper into this subject: Straight-bladed training swords were called Rappier while the training sabre most often was called Fechtsäbel meaning fencing sabre. Most fencing manuals agreed that you should begin training with the lighter Rappier and only when you have gained some proficiency in its use switch to heavier sabre.

The weapon featured in most German manuals on Hiebfechten, especially in the early period, was the Glockenschläger or Glockenrappier, meaning bell guard rapier. It consisted of a straight blade mounted to a hilt constructed out of a grip with oval cross-section, a crossbar, a knuckle bow and a bowl-shaped bell guard. It resembled pretty much the form of the earlier Rapiers.

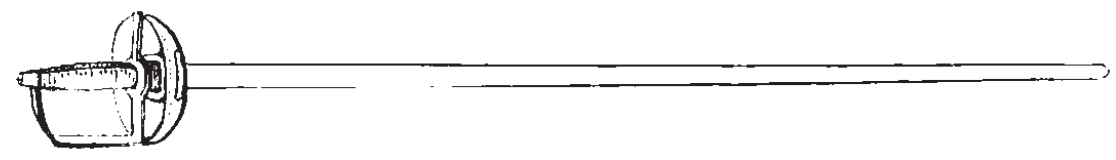

Fig. 8-Glockenschläger-Glockenrappier

The weapon favoured by the Roux family was the Korbscbläger or Korbrappier, aka basket hilt rapier. It consisted of a straight blade with a basket hilt, a grip with a thumb groove and a leather loop to insert the forefinger. The Korbrappier offered significant more protection to the fencers hand than the Glockenrappier. Perhaps this is the reason it became more popular over time and is still used today widely in German student fraternities.

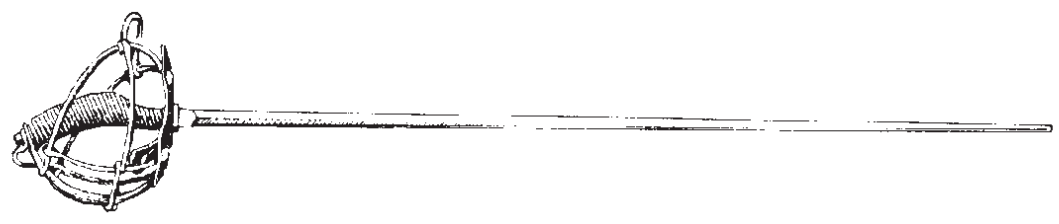

Fig. 9 - Korbschläger - Korbrappier 
The hilt of the Korbsäbel is very similar to the one of the Korbscbläger. The only remarkable difference is the presence of a hook or nose on the front plate of the basket, facing the back of the blade. This hook was sometimes used to control the opponent's blade during the execution of certain techniques. ${ }^{6}$



Fig. 10 - Korbsäbel-Fechtsäbel

Other types of sabres were also sometimes used, such as the Bügelsäbel with a stirrup-hilt and the Muschelsäbel, featuring a bowl-shaped guard. These were especially popular in military circles. Often fencing manuals from Austria describe this kind of practice sabre. Muschelsäbel are still used in the current practice of Pennälerfechten, in which primarily grammar school pupils fight with blunt sabres to the bare upper body. The following Muschelsäbel features a Scbläger-like grip. Many of these weapons had a back-strap grip, though, just like most of the service-sabres.

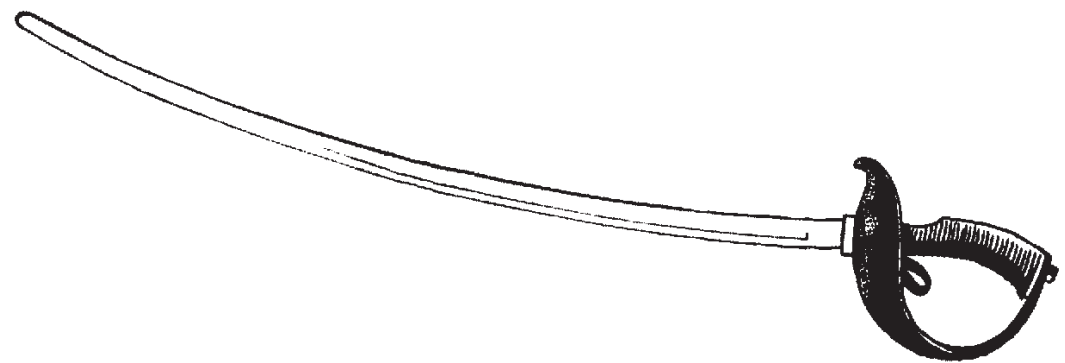

Fig. 11 - Muschelsäbel

\footnotetext{
${ }^{6}$ Roux, Ludwig Caesar, Die Hiebfechtkunst: eine Anleitung zum Lehren und Erlernen des Hiebfechtens aus der verbangenen und steilen Auslage mit Berücksichtigung des akademischen Comments (Jena: Verlag Hermann Pohle, 1885), p. 117: "Die Pauksäbel haben hinten am Korb, an der Scheibe desselben, dem vorderen Bügel entgegengesetzt, einen aufwärts gebogenen Haken als Verzierung. In dem Raume, der zwischen diesem Haken und dem Rücken von dem Anfang der ganzen Stärke der Klinge liegt, kann man des Gegners halbe Schwäche der Klinge so fest fassen, dass er oft nicht im stande ist, sich los zu machen; er ist gleichsam bis zum vollendeten Schnitte unser Gefangener.”
} 
In all these training weapons the blade was divided into four areas, according to the amount of leverage possible: the full strong, the half strong, the half weak and the full weak.

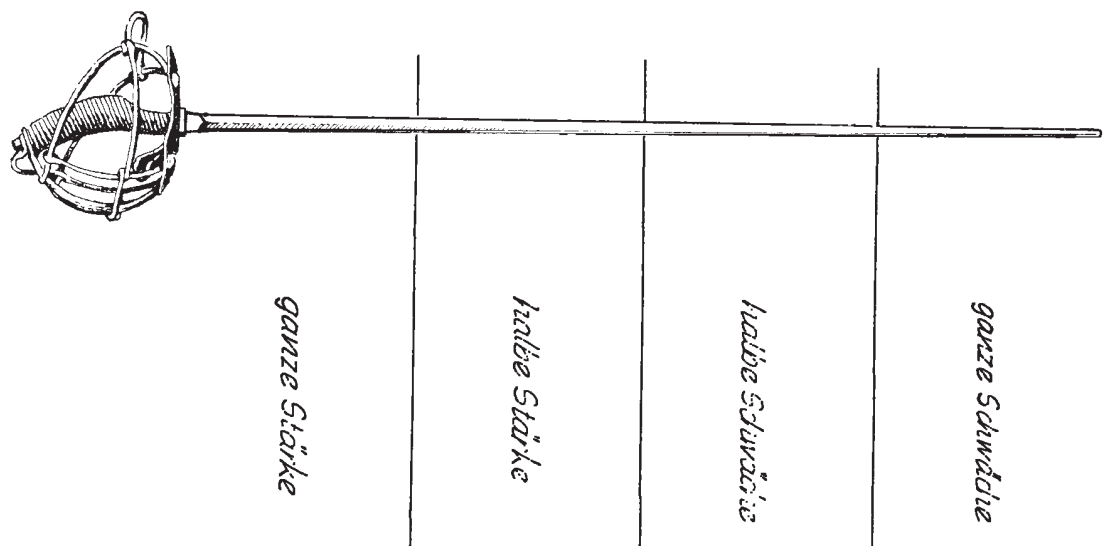

Fig. 12 - The division of the blade

\section{CHARACTERISTICS OF GERMAN CUT FENCING IN THE 19TH CENTURY SEEN THROUGH THE MANUALS OF MEMBERS OF THE ROUX FAMILY}

One of the most typical features of German swordplay in the $18^{\text {th }}$ and $19^{\text {th }}$ century is the position of the upper body. Nearly all documented systems take care to incline the torso forwards from the hip. This is equally true for both cut and thrust fencing. One of the specified reasons for this is that in this position the ribs were regarded to protect the internal organs better against blade penetration than in an upright posture. ${ }^{7}$

\footnotetext{
7 e. g. Roux, L. C., Die Hiebfechtkeunst (1885), p. 94: "Die Position bei dem Hiebfechten aus der steilen Auslage, Taf. XIV Fig. 1 u. 2, ist im allgemeinen ganz dieselbe, wie bei dem Fechten aus der verbangenen Auslage, siehe $\int$ 9, nur wird der Unterleib noch mehr eingezogen und der Oberkörper so weit nach vorn gelegt, dass sich die Rippen fest aneinander legen. Auf diese Weise ist schon die Position halbe Verteidigung, indem uns der Gegner mit seinen tiefen Hieben kaum zu erreichen vermag. Durch das feste Aneinanderlegen der Rippen bildet unser Oberkörper einen natürlichen Panzer, so dass auch ein nicht parierter Hieb nach der Brust nicht in die edlen Teile des Körpers einzudringen vermag."
} 


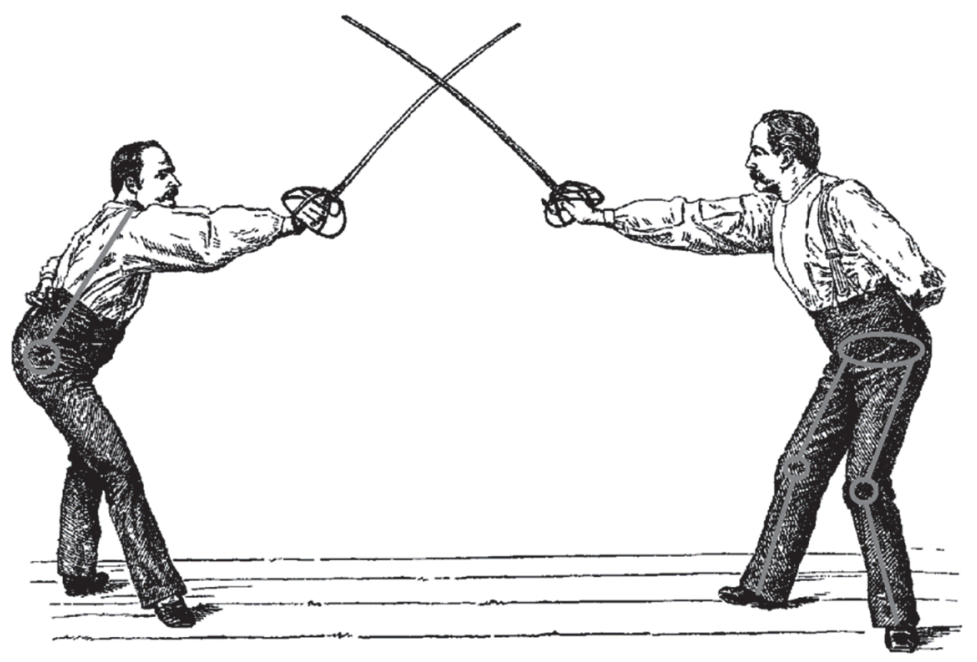

Fig. 13 - Body lean and leg position in L. C. Roux's "Die Hiebfechtkunst"

In the guard position for Hiebfechten the weight was generally kept mostly on the bent back leg and the front leg was carried more or less straight. This, in addition with the forward lean, made it harder for the opponent to attack the advanced leg. An additional advantage was that the fencer could accompany a feint with a shift forwards without having to take an actual step. Not all German systems agreed with this leg position, though. Johann Adolf Werner, for example, in his works ${ }^{8}$ describes a guard position with the front leg bent and the rear leg more or less straight while still keeping the forward tilt of the body. This was true for most of the manuals belonging to the "Turner Movement" which form another important corpus of Hiebfechten manuals.

\footnotetext{
8 e.g. Werner, Johann Adolf, Versuch einer theoretischen Anweisung zur Fechtkunst im Hiebe (Leipzig: Verlag Hartmann, 1824)
} 




Fig. 14 - Body lean and weight distribution in Werner's "Anweisung zur Fechtkunst"

The Roux Family, however, insisted on the previously described position. Additionally they advocated to put the front foot a little bit to the side to create a kind of $\mathrm{v}$-shaped stance. This was done to gain more stability in striking and parrying with cutting weapons. ${ }^{9}$ In thrust fencing they continued to use a linear stance.
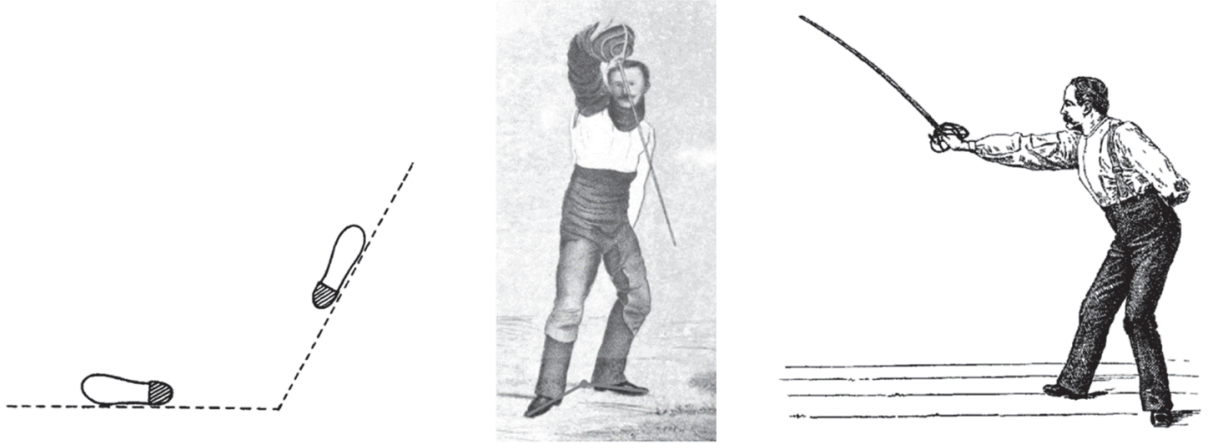

Fig. 15 - Examples for the v-shaped stance

Two basic forms of guards were being used, one with the tip up, later called Steile Auslage meaning "steep guard", and one with the tip down, later called Verbangene Auslage or "hanging guard". While at first both guard positions were used with the Schläger and the

\footnotetext{
${ }_{9}$ Roux, Friedrich August Wilhelm Ludwig, Deutsches Paukbuch (Jena: Verlag von Friedrich Mauke, 1857), p. 19: "Nun werden aber bei unsern Paukereien meistens Seitenbiebe angewendet, wie steile Quart, steile Terz. und Tiefquart. Hiersteht dann der Fechter in unserer Stellung viel fester und kann namentlich fester pariren, aber, was eine Hauptsache ist, auch sicherer und fester contra tempo schlagen, als wenn er die Füsse hinter einander stellt."
} 
sabre, it later became customary to use the Verbangene Auslage exclusively with the Schläger and the Steile Auslage only with the sabre. The weapon arm typically was held straight out forward ${ }^{10}$, "hiding" behind the guard of the sword, especially in the Steile Auslage. The following image from Deutsches Paukbuch shows both the Verhangene (1) and the Steile Auslage (2) in addition to a faulty guard (3).

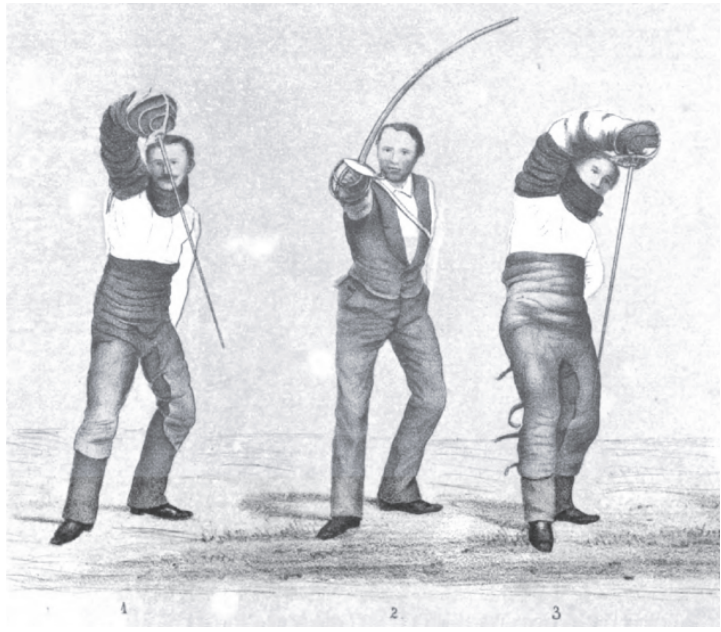

Fig. 16 - Guard positions in "Deutsches Paukbuch"

Cuts were named by the respective hand position in old, Italian fencing terminology. For instance, a cut with the hand in position of Quart (thumb to the right and pinkie to the left for a right-handed fencer) is also called Quart. The following diagram, showing the cuts as seen from the fencer executing them, will make this terminology a little clearer. It is taken from L. C. Roux's Die Hiebfecbtkunst ${ }^{11}$ and shows the pattern of cuts that is still used today in academical fencing. Different patterns were used during the time period relevant to this article. All had in common that the names of the cuts corresponded to the matching hand position, sometimes differing from the original Italian meaning.

\footnotetext{
${ }^{10}$ Roux, F. A. W. L., Deutsches Paukbuch (1857), p. 20: “Alle Hiebe müssen aus dem Handgelenk, mit geradem Arm angezogen und sodann mit gut gestrecktem Arm scharf ausgeschlagen werden, denn das geringste Anziehen, Krummachen des Arms, hat eine Blösse zur Folge.”

11 Roux, L. C., Die Hiebfechtkunst (1885)
} 

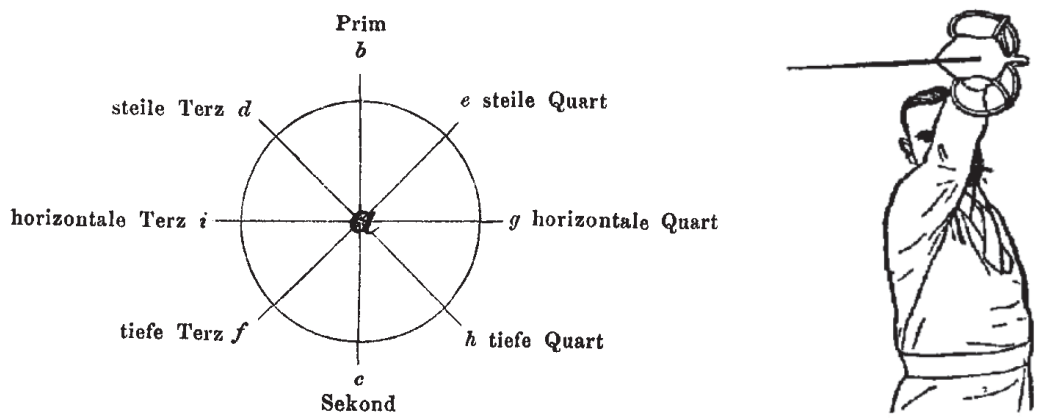

Fig. 17 - Diagram with the cutting lines

Fig. 18 - borizontal Quart

Cutting diagrams like the one depicted above were already used in $16^{\text {th }}$ century Germany. Joachim Meyer for instance used a similar one in his Dusack chapter.

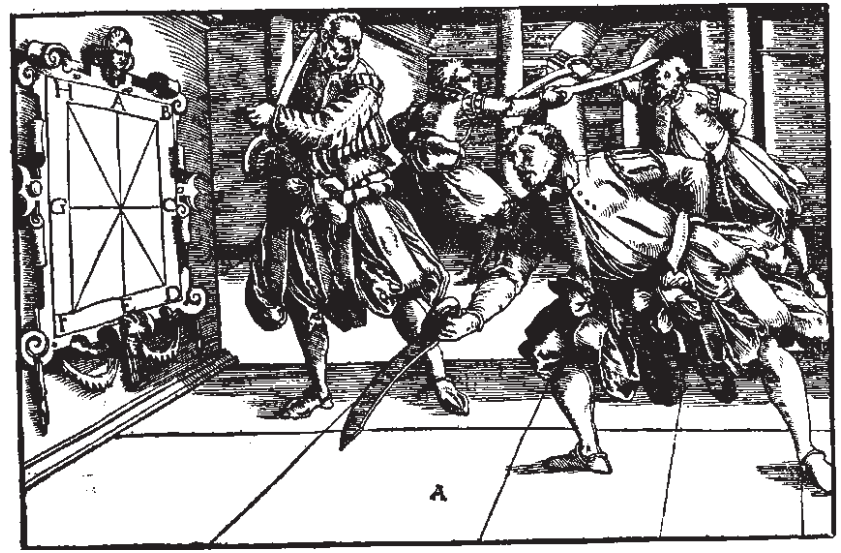

Fig. 19 - Cutting diagram out of Meyer's 1570 fencing manual

It is interesting to note that German Hiebfechten seems to have retained many features of earlier German fencing styles, giving it a distant look compared to other fencing systems of this time. We are going to have a look at some of these features in the course of this article.

Great importance was laid on what they called gedeckte Hiebe or covered strikes. This meant that the fencers tried to strike in a way that excluded an opponent's most probable counterattack. In striking the sword was held quite loose, so that the grip of the weapon could slide a little bit through the hand, potentially enabling the weapon to strike behind 
the opponent's guard. This was called Schwippen ${ }^{12}$ and in the author's experience is especially effective with straight bladed swords.
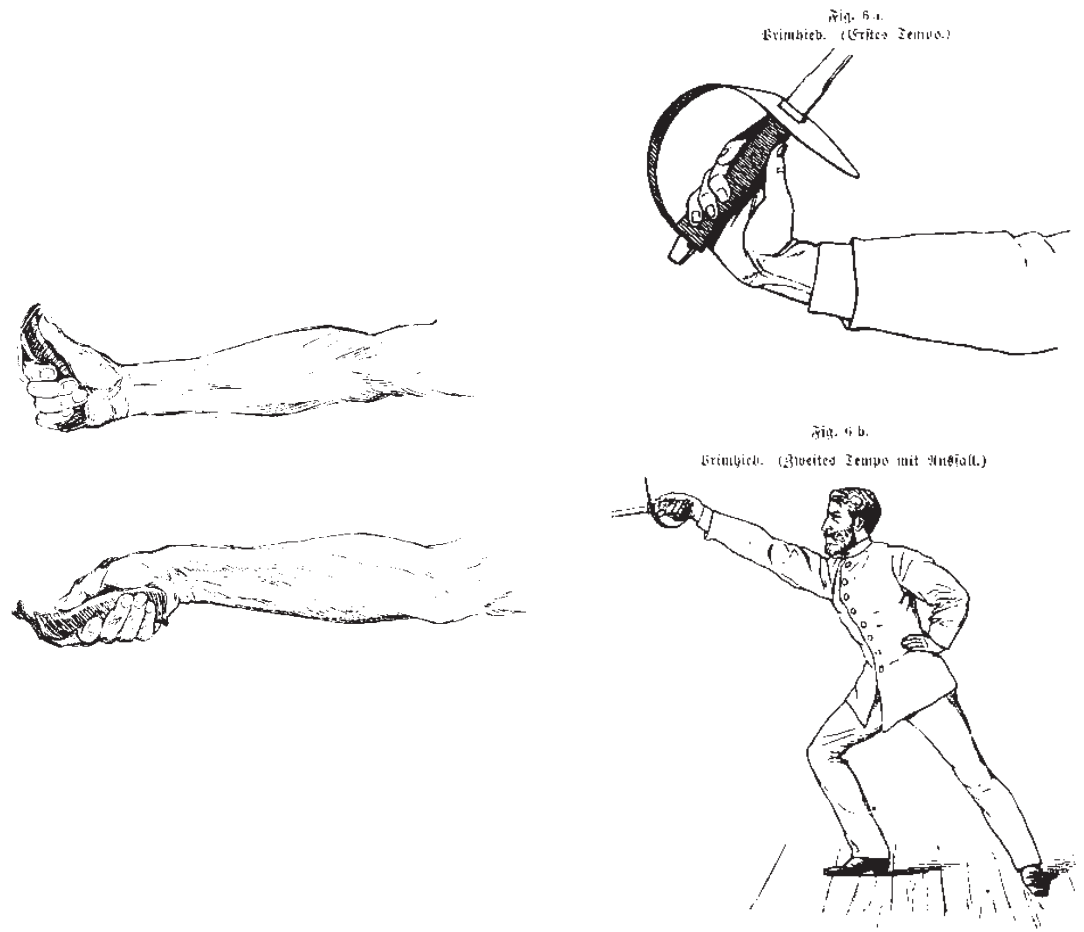

Fig. 20 - Close-up of the

"Schwippen"

Fig. 21 - "Schwippen" with the "Primbieb"

Loosing the weapon was prevented by putting the finger either over the crossguard of the Glockenschläger or through the finger loop of the Korbschläger. A characteristic example of this kind of striking is the Primbieb that bears striking resemblance to the Gefehrhau of Leckuchner's late $15^{\text {th }}$ century manual on fencing with the Messer.

\footnotetext{
12 Roux, L. C., Die Hiebfechtkunst (1885), p. 23: Sollen sich unsere Hiebe schwungvoll und trefffähig gestalten, so macht sich noch notwendig, dass wir den Griff nicht in der Weise festhalten, wie ibn die Hand in der Auslage umschliesst, sondern dass wir denselben in dem Augenblick, in welchem wir unsere Hiebe austeilen, in der Hand etwas nachgleiten lassen. Dabei müssen aber die drei letzten Finger, welche den Griff umschliessen, noch Fühlung mit demselben behalten.
} 


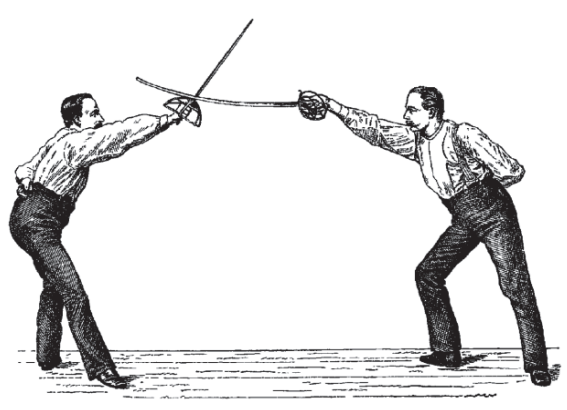

Fig. 22 - The "Primbieb" with the sabre

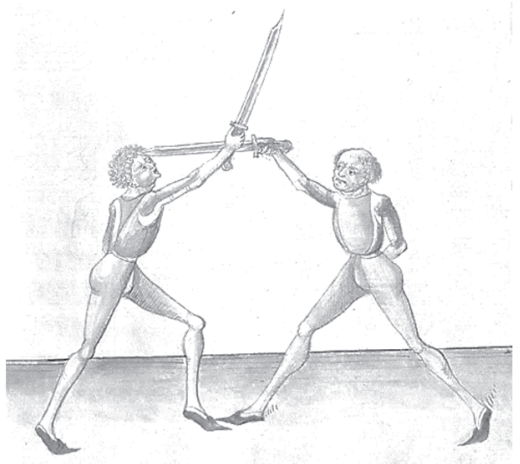

Fig. 23-Leckuechner's

"Geferhau"

The attacks were either delivered with a Kniebengwechsel, meaning bending the straight front leg and straightening the rear leg, or with a short lunge, around a foot in length. Footwork generally was relatively static. Retreating with the defence was frowned upon. If the opponent was so nasty to retreat, it was accepted to advance with the attack. In certain cases traversing was also possible but was considered dangerous.
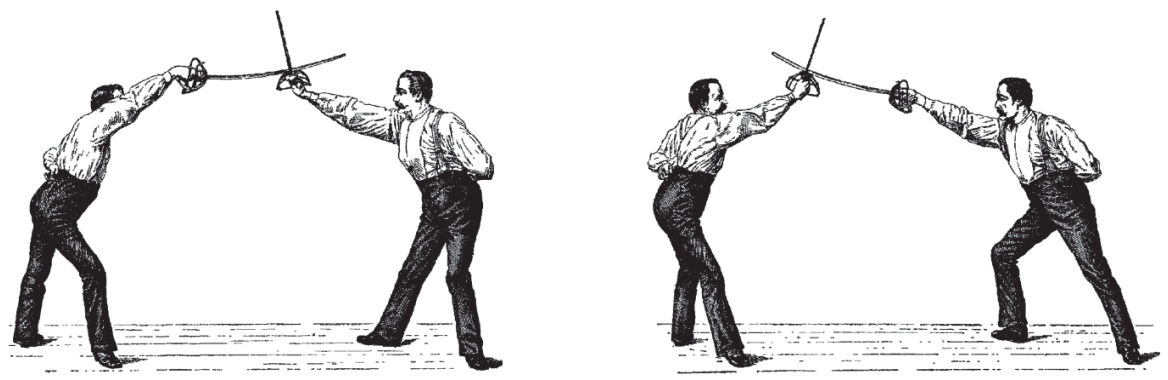

Fig. 24 - Parry with the weight shifted backwards followed by a counterattack with the weight shifting forwards and a short lunge

So standing your ground and being on the offensive was viewed as advantageous. This leads us to another typical feature of the German Hiebfechten - attacking in contratempo. The concept of contratempo has to do with the timing of the attack. Hiebfechten differentiated between three variations of timing: Anbieb - attacking before the opponent, Nachbieb attacking after having defended against the opponent's attack and A-Tempo-Hieb attacking at the same time as the adversary. Vorbiebe and Kontratempobiebe were special forms of A-Tempo-Hiebe. The Vorbieb was a strike delivered into the preparation of the opponent's attack (Seemann-Kahne, Akademische Fechtschule: Unter Vorbieben versteht man diejenigen Hiebe, die den Gegner wäbrend seines Angriffes treffen sollen, und zwar warden sie einerseits in den "Hiebanzug", andererseits in eine Fintbewegung gefübrt.) The Kontratempobieb was 
not only delivered in the same time as the opponent attacked, but it also covered against the opponent's attack, defending and attacking at the same time. People familiar with earlier German fencing will recognise the similarity to Liechtenauers Vor, Nach and Indes and the way some of the Verborgene Hiebe of Liechtenauer were used to simultaneously defend and attack. The Kontratempobiebe were especially efficient with straight-bladed swords. With the curved sabre it was preferred to catch the opponents blade with the angle between blade and guard and to push a Schnitt or slicing cut into the opponent's face.
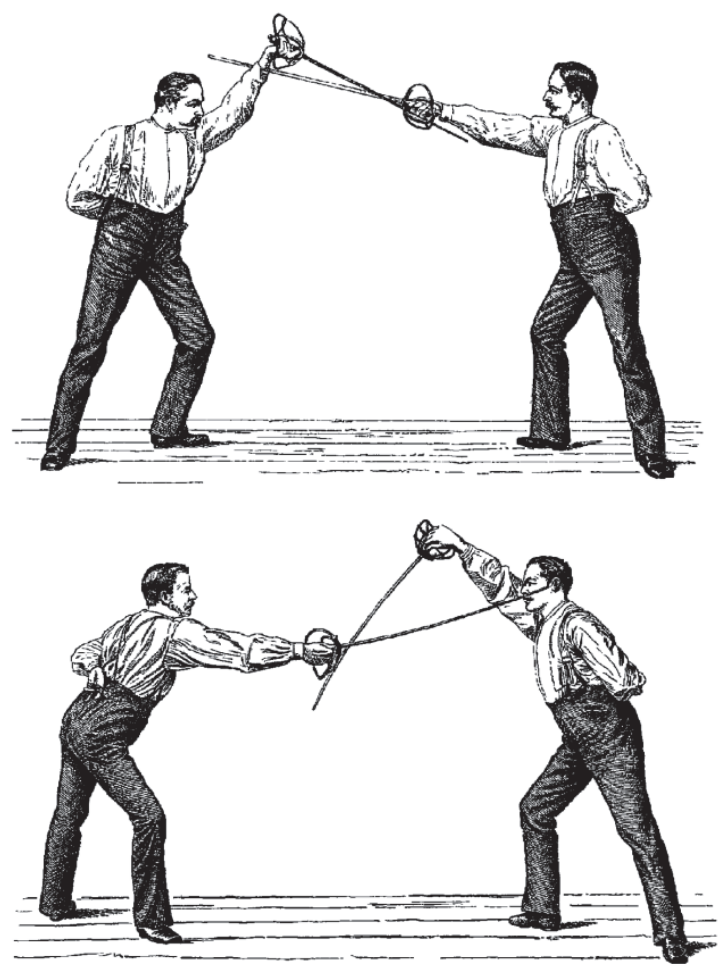

Fig. 25 - A "Kontratempohieb" with the Schläger

Fig. 26-A "Schnitt" with the Sabre 


\section{CHARACTERISTICS OF THE OLDER SYSTEM OF CUT FENCING (EXEMPLIFIED BY ANWEISUNG ZUM \\ HIEBFECHTEN)}

In his early work Anweisung zum Hiebfechten ${ }^{13}$ F. A. W. L. Roux described a guard position that is quite different from the one he later advocated. He describes a position with the hand held high and turned a little diagonally. The point was kept a little lower, stretched forward to bind the opponent's blade. Holding the point forward keeps the opponent at bay and makes it easier to transition to thrust fencing in earnest combat. This was warned against in later Hiebfechten manuals in order to prevent accidentally running into the point while lunging forward.



Fig. 27 - Guard position advocated in "Anweisung qum Hiebfechten"

He mentions an older form of guard position with the blades pointing forwards and upwards, quite similar to what would later become the Steile Auslage for sabre combat: In den älteren Zeiten, wie man in alten Lehrbüchern über Hiebfechten noch finden kann, legte man sich mit hoher Klinge in Terz, aus, wobei die Klinge gebunden, d. h. die Klinge an die des Gegners angelegt wurde. ${ }^{14}$

\footnotetext{
13 Roux, F.A.W.L. - Scheidler, Anweisung zum Hiebfechten mit graden und krummen Klingen (1840)

${ }^{14}$ For the Steile Auslage see Fig. 13.
} 




Fig. 28 - "Old guard" mentioned in "Anweisung zum Hiebfechten"

We can see this kind of point-forward guard applied in the following Mensur scene taken from Fick's Auf Deutschlands bohen Schulen:



Fig. 29 - A Göttingen Mensur scene from 1808

The cuts were five in number, detailed in the following diagram. A sixth cut, called polnische Quart was executed along the same line as the Primbieb, but with the hand turned into an extreme Quart position. There is also a short mention of a cut delivered straight downwards to the head, the shoulder or arm, but it was considered useful only for heavy cavalry: Man hat auch eine obere balb Terz halb Quart nach der Mitte des Kopfes, auf die Schulter und den Arm, allein dieser Hieb ist nur der schweren Cavallerie zu empfeblen. 


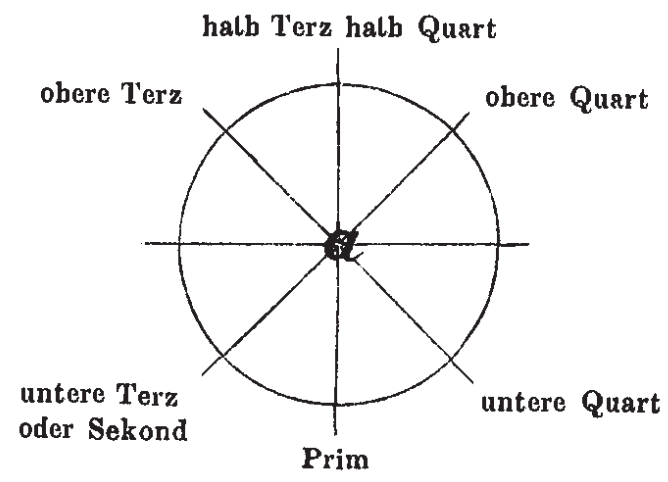

Fig. 30 - Pattern explaining the cuts of "Anweisung zum Hiebfechten"

Parries were done point-down as well as point-up, depending on the circumstances and there was no distinction between the methods of using a straight or a curved blade. Retreating and turning were still an option, while not the preferred method of defence. He describes turning around the front foot with the parry similar to what Joachim Meyer had written about nearly three hundred years earlier. ${ }^{15}$



Fig. 31 - A counterattack to the arm withdrawing the leg

\footnotetext{
${ }^{15}$ E.g. Roux, F. A. W. L., Anweisung zum Hiebfechten: "Unter Voltiren versteht man eine geschickte Wendung des Körpers, welche dadurch hervorgebracht wird, dass man gleichzeitig mit der Parade der obern und untern Quart des Gegners den linken Fuß unter demselben Winke., und gerade um so viel rechts hinter den rechten set:t, als er in der Position vorber links von demselben gestanden hat. Mit dem Nachbiebe selbst aber wird der rechte Fuss nicht in gerader Linie nach dem Gegner zu, sondern so weit rechts gesetzt, als zu einer reinen Position erforderlich ist..."
} 


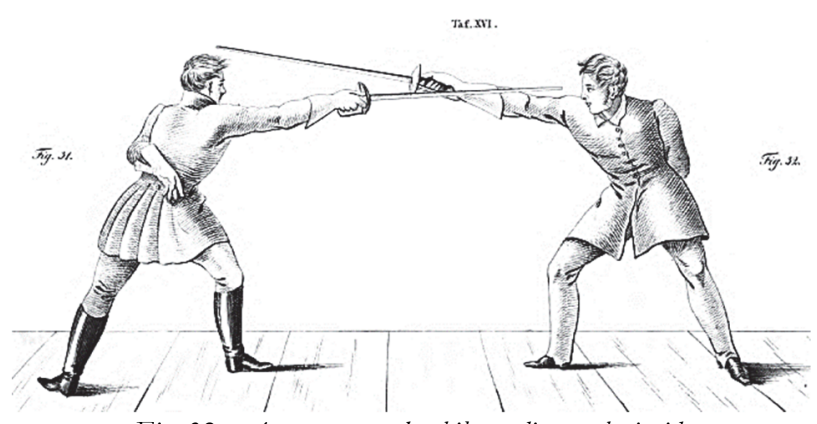

Fig. 32 - A counterattack while evading to the inside

\section{CHARACTERISTICS OF THE SAFER SYSTEM OF CUT FENCING FOR STUDENTS:}

In his quest to make the Mensur safer F.A.W.L. Roux promoted changes in the fencing style of the University students. One of the dangers of the old point-forward guards was that a fencer could lunge into the outstretched point of his opponent, causing a serious thrust wound. To prevent this, F. A. W. L. Roux made the fencers hold their point more downwards and to the side (F. A. W. L. Roux, Deutsches Paukbuch (1857), p. 20: "Die Spitze ist verhangen seitwärts gewendet, damit der Gegner sich nicht bineinrennen kann."), thus making the guard similar to one he described in Anweisung zum Hiebfechten as being used by "some fencers". At this time he clearly did not recommend it.

TC.I.
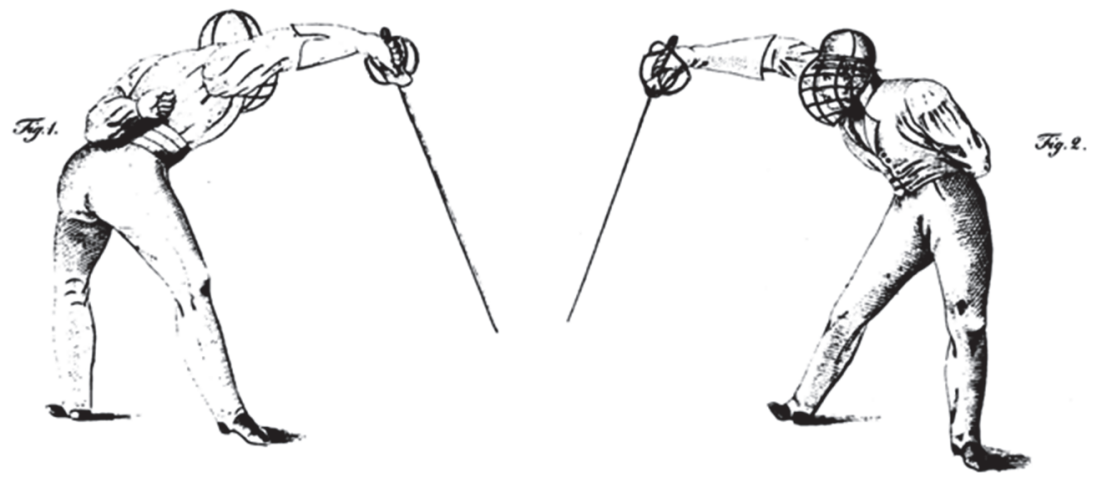

Fig. 33 - Hanging guard used by "some Fencers"

Regarding cuts he laid more importance on the strike straight from above and introduced the horizontal strikes to his system, making the cutting pattern completely symmetrical. This new pattern with the corresponding nomenclature was bound to remain standard in academical fencing until the present time. 


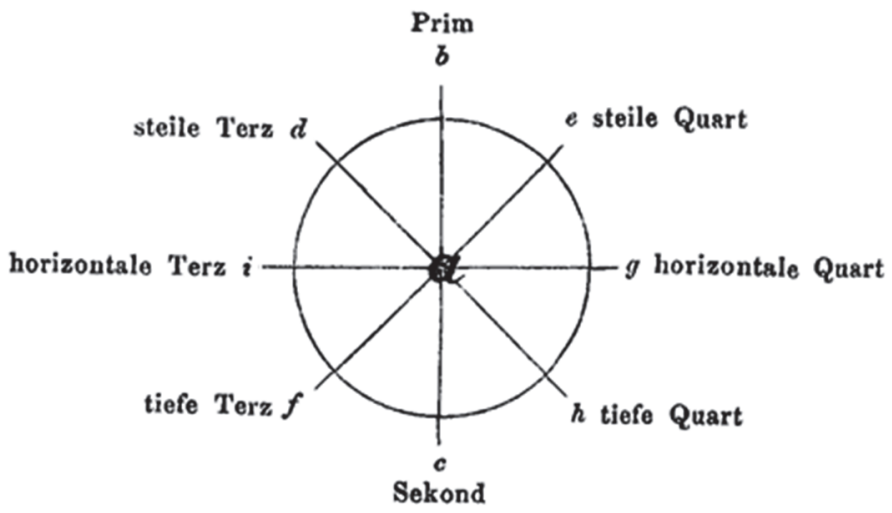

Fig. 34 - Cutting pattern of the new method

Seemingly the most important modification to the old style was his acceptance of using the safety equipment of the fencers to parry. During the development of Mensur fencing more and more safety measures had been introduced to lessen the mortality of the student's fights. It started with bandages for the wrist and neck, then aprons or padded trousers to cover the stomach/groin area. Finally bandages for the full arm had been introduced. Though not intended for this, students surely used them in fights to avoid a wound when a regular parry was not possible any more. F. A. W. L. Roux acknowledged this as a viable mode of defence: Der Stulp ist nun aber eine Schutzwaffe, die man einmal bei der Paukerei hat und haben will, warum sollte man das also, was einmal da ist, im Nothfall nicht benutzen?

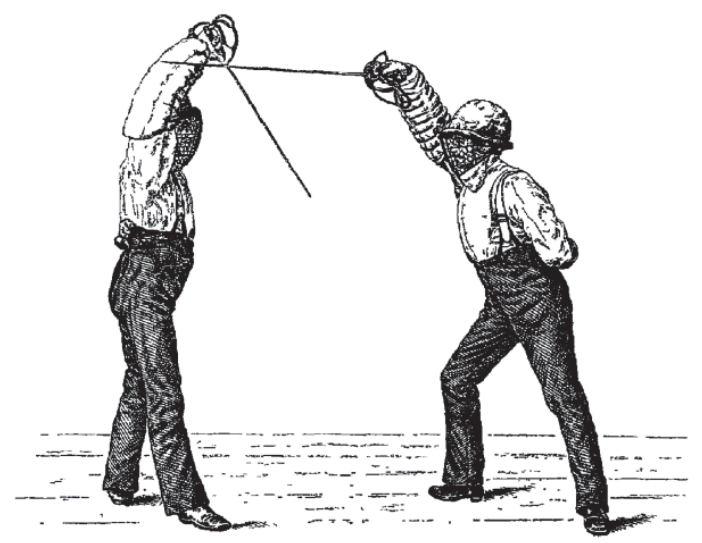

Fig. 35 - Parry of a Hochterz, with the arm protection (Paukstulp)

In the following years this decision led to further changes, like the introduction of more safety equipment and complete abolishment of the lunge, removing the students' Mensur more and more from a "real" fight, whatever this may be. 


\section{BIBLIOGRAPHY}

\section{VII.1. Genealogy of the Roux family}

Hochfürstl S. Weimar- und Eisenachischer Hof-und Adreß-Calender auf das Jahr 1806, (Jena: J.

E. G. Göpferdt, 1806)

Seemann-Kahne, Christian, Die Kreussler in Jena (Jena: Verlag von Bernhard Vopelius, 1912)

Roux, Paul, Die Fechtmeisterfamilien Kreußler und Roux: Ein geschichtlicher Rückblick auf die deutsche Fechtkunst vom Mittelalter bis zum Anfang des gegenwärtigen Jahrbunderts (Jena: Frommannsche Buchdruckerei, 1911)

Feicht, Ulrike, Wilhelm Roux (1850 - 1924) - seine ballesche Zeit (Medizinische Fakultät der Martin-Luther-Universität Halle-Wittenberg, 2007),

http://www.ahnen.roux.de/

\section{VII.2. Literary works of the Roux family}

Roux, Heinrich Friedrich, Versuch über das Contrefechten auf die rechte und linke Hand, (Jena: Crökersche Buchhandlung, 1786)

Roux, Heinrich Friedrich, Lebrbuch der deutschen Fechtkunst (Jena, 1786)

Roux, Johann Adolf Karl, Grundriss der Fechtkunst als gymnastische Übung betrachtet (Jena: Stranckmannsche Buchdruckerey, 1798)

Roux, Johann Adolf Karl, Gründliche und vollständige Anweisung in der deutschen Fecht-Kunst (Jena: Wolfgang Stahls Buchhandlung 1798)

Roux, Johann Adolf Karl, Die deutsche Fechtkunst, enthaltend eine theoretisch-praktische Anweisung zum Stossfecbten (Leipzig: Barth, 1817)

Roux, Johann Adolf Karl, Theoretisch-praktische Anweisung über das Hiebfechten (Fürth: Büreau für Literatur, 1803)

Roux, Johann Wilhelm, Anleitung zur Fechtkunst nach mathematisch-physikalischen Grundsätzen bearbeitet (Jena: Akademische Buchhandlung, 1808)

Roux, Friedrich August Wilhelm Ludwig - Scheidler, Karl Hermann, Anweisung zum Hiebfechten mit graden und krummen Klingen (Jena: Verlag von Friedrich Mauke, 1840)

Roux, Johann Adolf Karl - Roux, Friedrich August Wilhelm Ludwig, Über das Verhältnis der deutschen Fechtkunst zum Ehrenduell sowohl im allgemeinen, als auch für Universitäten insbesondere mit Berücksichtigung der Mittel, die Duelle zu verbüten, oder sie wenigstens unscbädlich zu machen und zu mindern (Erfurt: Verlag Hennings \& Hopf, 1841)

Roux, Friedrich August Wilhelm Ludwig, Deutsches Paukbuch (Jena: Verlag von Friedrich Mauke, 1857)

Roux, Friedrich August Wilhelm Ludwig, Die Kreussler'sche Stossfechtschule. Zum Gebrauch für Academieen und Militärschulen nach Mathematischen Grundsätzenen (Jena: Verlag von Friedrich Mauke, 1857) 
Roux, Ludwig Caesar, Die Hiebfechtkunst: eine Anleitung zum Lehren und Erlernen des

Hiebfechtens aus der verhangenen und steilen Auslage mit Berücksichtigung des akademischen

Comments (Jena: Verlag Hermann Pohle, 1885)

Roux, Paul, Das Säbelfechten "rechts gegen rechts" und "links gegen links" (Jena: Verlag

Hermann Pohle, 1899)

\section{VII.3. Works by Dr. Karl Hermann Scheidler}

Scheidler, Karl Hermann, Ueber die Abschaffung der Duelle unter den Studirenden (Jena:

Bran'sche Buchhandlung, 1829)

Scheidler, Karl Hermann, Ueber das deutsche Studentenleben und die Nothwendigkeit einer innern, von den Studirenden selbst ausgehenden Reform desselben, (Jena: Bran'sche Buchhandlung, 1842)

Scheidler, Karl Hermann, Hieb oder Stoß (Jena: Frommannsche Buchdruckerei, 1843)

\section{VII.4. Other works}

Behr, Friedrich Leopold, Flüchtige Bemerkungen über die verschiedene Art zu fechten einiger Universitäten (Halle: 1791)

Werner, Johann Adolf Ludwig, Versuch einer theoretischen Anweisung zur Fechtkunst im Hiebe (Leipzig: Verlag Hartmann, 1824)

Werner, Johann Adolf Ludwig, Das Ganze der Gymnastik (Meissen: Verlag Friedrich Wilhelm Goedsche, 1834)

Werner, Johann Adolf Ludwig, Militär-Gymnastik (Leipzig: Arnoldische Buchhandlung, 1850)

Bluth, ..., Praktische Anleitung zum Unterricht im Hiebfechten (Berlin: Ernst Siegfried Mittler und Sohn, 1883)

Fix, Nathanaël Theodore, L'Escrime dans les universités allemandes d'apres Ludwig Caesar Roux, Fried. Schulze, W. Fehn etc. (Paris: Librairie Militaire de L. Baudoin, 1896)

Fick, Richard, Auf Deutschlands hohen Schulen (Berlin: Verlag Hans Ludwig Thilo, 1899)

Seemann-Kahne, Christian - Seemann-Kahne Friedrich, Akademische Fechtschule (Leipzig: Verlag J. J. Weber, 1926)

Angerer, Albin, Anleitung zum Fechten mit dem Korbschläger (Würzburg: Verband Alter Corpsstudenten, 1979)

Huhle, Henner, Die Entwicklung des Fechtens an deutschen Hochschulen in: Historia Academica - Heft 5 (Stuttgart: Verlag Heinrich Fink GmbH + Co., 1983)

\section{IMAGES}

Fig. 1 - Sabre Mensur scene, "Deutsches Paukbuch", Friedrich August Wilhelm Ludwig Roux, Verlag von Friedrich Mauke, 1857 
Fig. 2 - Francois Roux, "Die Fechtmeisterfamilien Kreußler und Roux" by Paul Roux, Frommannsche Buchdruckerei, Jena, 1911

Fig. 3 - Johann Friedrich Gottfried Roux , "Die Fechtmeisterfamilien Kreußler und Roux" by Paul Roux, Frommannsche Buchdruckerei, Jena, 1911

Fig. 4 - Johann Adolph Karl Roux, "Die Fechtmeisterfamilien Kreußler und Roux" by Paul Roux, Frommannsche Buchdruckerei, Jena, 1911

Fig. 5 - Johann Wilhelm Roux, "Die Fechtmeisterfamilien Kreußler und Roux” by Paul Roux, Frommannsche Buchdruckerei, Jena, 1911

Fig. 6 - Ludwig Caesar Roux, "Die Fechtmeisterfamilien Kreußler und Roux” by Paul Roux, Frommannsche Buchdruckerei, Jena, 1911

Fig. 7 - Friedrich August Wilhelm Ludwig Roux, "Die Fechtmeisterfamilien Kreußler und Roux" by Paul Roux, Frommannsche Buchdruckerei, Jena, 1911

Fig. 8 - Glockenschläger - Glockenrappier, "Versuch einer theoretischen Anweisung zur Fechtkunst im Hiebe”, Johann Adolf Ludwig Werner, Verlag Hartmann, Leipzig, 1824

Fig. 9 - Korbschläger - Korbrappier, “Anleitung zum Fechten mit dem Korbschläger”, Albin Angerer, Verband Alter Corpsstudenten VAC, Würzburg 1961, Marl 1979

Fig. 10 - Korbsäbel - Fechtsäbel, "Das Säbelfechten "rechts gegen rechts” und "links gegen links”, Paul Roux, Verlag Hermann Pohle, 1899

Fig. 11 - Muschelsäbel, "Das Säbelfechten "rechts gegen rechts" und "links gegen links”, Paul Roux, Verlag Hermann Pohle, 1899

Fig. 12 - The division of the blade, "Anleitung zum Fechten mit dem Korbschläger", Angerer, Albin, Anleitung zum Fechten mit dem Korbschläger, Verband Alter Corpsstudenten, Würzburg, 1979

Fig. 13 - Body lean and leg position in L. C. Roux’s "Die Hiebfechtkunst”, "Die Hiebfechtkunst: eine Anleitung zum Lehren und Erlernen des Hiebfechtens aus der verhangenen und steilen Auslage mit Berücksichtigung des akademischen Comments", Verlag Hermann Pohle, 1885

Fig. 14 - Body lean and weight distribution in Werner's "Anweisung zur Fechtkunst", "Versuch einer theoretischen Anweisung zur Fechtkunst im Hiebe", Johann Adolf Ludwig Werner, Verlag Hartmann, Leipzig, 1824

Fig. 15 - Examples for the v-shaped stance, composed out of three images, from a) "Akademische Fechtschule", Christian und Friedrich Seemann-Kahne, Verlag J. J. Weber, 1926; b) "Deutsches Paukbuch", Friedrich August Wilhelm Ludwig Roux, Verlag von Friedrich Mauke, 1857; and c) 'L'Escrime dans les universités allemandes d'apres Ludwig Caesar Roux, Fried. Schulze, W. Fehn etc.”, Colonel Fix, Librairie Militaire de L. Baudoin, Paris, 1896

Fig. 16 - Guard positions in "Deutsches Paukbuch", "Deutsches Paukbuch", Friedrich August Wilhelm Ludwig Roux, Verlag von Friedrich Mauke, 1857 
Fig. 17 - Diagram with the cutting lines, "Die Hiebfechtkunst: eine Anleitung zum

Lehren und Erlernen des Hiebfechtens aus der verhangenen und steilen Auslage mit Berücksichtigung des akademischen Comments”, Verlag Hermann Pohle, 1885

Fig. 18 - horizontal Quart, “L’Escrime dans les universités allemandes d'apres Ludwig

Caesar Roux, Fried. Schulze, W. Fehn etc.", Colonel Fix, Librairie Militaire de L. Baudoin, Paris, 1896

Fig. 19 - Cutting diagram out of Meyer's 1570 fencing manual, "Gründtliche

Beschreibung der Kunst des Fechtens”, Joachim Meyer, Straßburg, 1570

Fig. 20 - Close-up of the "Schwippen", "Anleitung zum Fechten mit dem

Korbschläger”, Albin Angerer, Verband Alter Corpsstudenten VAC, Würzburg 1961, Marl 1979

Fig. 21 - "Schwippen" with the "Primhieb", "Praktische Anleitung zum Unterricht im Hiebfechten“, Bluth, Verlag Ernst Siegfried Mittler und Sohn Berlin, 1883

Fig. 22 - The "Primhieb" with the sabre, "L'Escrime dans les universités allemandes d'apres Ludwig Caesar Roux, Fried. Schulze, W. Fehn etc.", Colonel Fix, Librairie Militaire de L. Baudoin, Paris, 1896

Fig. 23 - Leckuechner's “Geferhau”, Cgm 582, Johannes Leckuechner, BSB München, 1482

Fig. 24 - Parry with the weight shifted backwards followed by a counterattack with the weight shifting forwards and a short lunge, "L'Escrime dans les universités allemandes d'apres Ludwig Caesar Roux, Fried. Schulze, W. Fehn etc.”, Colonel Fix, Librairie Militaire de L. Baudoin, Paris, 1896

Fig. 25 - A “Kontratempohieb” with the Schläger, "L'Escrime dans les universités allemandes d'apres Ludwig Caesar Roux, Fried. Schulze, W. Fehn etc.", Colonel Fix, Librairie Militaire de L. Baudoin, Paris, 1896

Fig. 26 - A "Schnitt" with the Sabre, "L'Escrime dans les universités allemandes d'apres Ludwig Caesar Roux, Fried. Schulze, W. Fehn etc.”, Colonel Fix, Librairie Militaire de L. Baudoin, Paris, 1896

Fig. 27 - Guard position advocated in "Anweisung zum Hiebfechten", "Anweisung zum Hiebfechten mit graden und krummen Klingen", Friedrich August Wilhelm Ludwig Roux, Verlag von Friedrich Mauke, 1840

Fig. 28 - "Old guard” mentioned in "Anweisung zum Hiebfechten”, "Anweisung zum Hiebfechten mit graden und krummen Klingen”, Friedrich August Wilhelm Ludwig Roux, Verlag von Friedrich Mauke, 1840

Fig. 29 - A Göttingen Mensur scene from 1808, “Auf Deutschlands hohen Schulen”, R. Fick, Verlag Hans Ludwig Thilo, Berlin, 1899

Fig. 30 - Pattern explaining the cuts of “Anweisung zum Hiebfechten”, altered image from "Die Hiebfechtkunst: eine Anleitung zum Lehren und Erlernen des Hiebfechtens aus der verhangenen und steilen Auslage mit Berücksichtigung des akademischen Comments", Verlag Hermann Pohle, 1885 
Fig. 31 - A counterattack to the arm withdrawing the leg, "Anweisung zum Hiebfechten mit graden und krummen Klingen”, Friedrich August Wilhelm Ludwig Roux, Verlag von Friedrich Mauke, 1840

Fig. 32 - A counterattack while evading to the inside, "Anweisung zum Hiebfechten mit graden und krummen Klingen“, Friedrich August Wilhelm Ludwig Roux, Verlag von Friedrich Mauke, 1840

Fig. 33 - Hanging guard used by "some Fencers", "Anweisung zum Hiebfechten mit graden und krummen Klingen”, Friedrich August Wilhelm Ludwig Roux, Verlag von Friedrich Mauke, 1840

Fig. 34 - Cutting pattern of the new method, "Die Hiebfechtkunst: eine Anleitung zum Lehren und Erlernen des Hiebfechtens aus der verhangenen und steilen Auslage mit Berücksichtigung des akademischen Comments”, Verlag Hermann Pohle, 1885

Fig. 35 - Parry of a Hochterz with the arm protection (Paukstulp), "L'Escrime dans les universités allemandes d'apres Ludwig Caesar Roux, Fried. Schulze, W. Fehn etc.”, Colonel Fix, Librairie Militaire de L. Baudoin, Paris, 1896 